\title{
TSMI METHODOLOGY OF REGISTRATION AND EVALUATION OF STREAM-BANK VEGETATION IN RURAL LANDSCAPE
}

\author{
Jan Škrdla, Petr Kupec ${ }^{1}$
}

Received 13 October 2010; Accepted 16 February 2011

\begin{abstract}
Stream-bank vegetation is an important constituent of landscape. Many streamside stands are not in good condition at present. The article presents methodology for the evaluation of stream-bank vegetation in rural landscapes. The goals of the paper are the registration and evaluation of stands as the basis for subsequent management proposal. Streams are divided into sections delimited by significant artificial or natural barriers. Within the frame of sections, segments are determined. Segments are parts of the section with similar general characteristics. Surveying includes site assessment, river valuation and streamside stand valuation. The results of evaluation are register outputs: maps and database. The register serves as a summary of stream-bank vegetation and as the basis of a management proposal.
\end{abstract}

Key words: stream-bank vegetation, streamside stand, rural landscape, registration of streambank vegetation, evaluation of stream-bank vegetation.

Souhrn: Vegetační doprovody (břehové a doprovodné porosty) vodních toků jsou důležitou součástí krajiny. Velká část vegetačních doprovodů vodních toků není v současné době $v$ dobrém stavu. Předmětem článku je prezentace metodiky evidence a hodnocení vegetačních doprovodů. Cílem této metodiky je zhodnocení stavu porostů, sloužící mimo jiné jako podklad pro následné hospodaření. Posuzované vodní toky jsou rozděleny do úseků, ohraničených přírodními nebo umělými bariérami. V rámci úseků se vymezí segmenty, části vegetačních doprovodů s podobnými charakteristikami. V rámci segmentů se hodnotí stanoviště, vodní tok, a vlastní porosty. Výsledkem metodiky jsou mapové a databázové výstupy. Mapy a databáze slouží jako souhrn o stavu vegetačních doprovodů a jako podklad pro návrh péče.

Klíčová slova: vegetační doprovody, břehové a doprovodné porosty, zemědělská krajina, evidence břehových porostů, hodnocení břehových porostů.

\section{Introduction}

Stream-bank vegetation is an important constituent of the rural landscape. Streamside stands consist of riparian and accompanying stands. Riparian stands are located on the riverbed, accompanying stands are located behind the bank edge. Bank-side trees and shrubs are

\footnotetext{
${ }^{1}$ Ing. et. Bc Jan Škrdla, Ing. Petr Kupec Ph.D., Department of Landscape Management, Faculty of Forestry and Wood Technology, Mendel Univerzity in Brno, 61300 Brno, Zemědělská 3, Czechia. E-mail: jan.skrdla@mendelu.cz, petr.kupec@mendelu.cz
} 
the important parts of the territorial system of ecological stability (TSES) (Šlezingr, Úradníček, 2003). Stream-bank vegetation performs many functions. Streamside stands protect banks against the effects of running water and drifting ice. Riparian and accompanying stands protect riverbed against silting by material transported by wind. Stream-bank vegetation shades the water surface and controls the rapid growth of weed hydrophytes. Riparian vegetation affects water quality. Riparian and accompanying vegetation provides refuge for fauna living near water, stands act as a natural bio-corridor. Bankside stands are important elements in landscape enhancement (Šlezingr, Úradníček, 2003), especially in the countryside. Bankside trees can produce wood. Recreational and sanitary functions are important too.

Stream-bank vegetation management is solved in Act No. 254/2001 Coll. on Water. The management is the duty of the owner or administrator. Bank protection is preferred. This is to prevent vegetation from obstructing the flow-off during flooding. Streamside stands are objects of other laws, for example Act No.114/1992 on Nature and Landscape Protection or Act No. 289/1995 on Forests.

In foreign countries, the issue of stream-bank vegetation and stream buffer zones is dealt with within the Platte County Zoning Order of 1990 or in the Land Development Manual ${ }^{2}$. In the European Union, water policy is established in Directive 2000/60/EC of the European parliament and of the council (Water framework directive). One key purpose of the Directive is to prevent further deterioration, and to protect and enhance the status of aquatic ecosystems. The Water framework directive provides definition of a body of surface water (water body). A body of surface water means a discrete and significant element of surface water (lake, a reservoir, a stream, river or canal, part of a stream, river or canal, a transitional water or a stretch of coastal water). The subject of the Directive is water policy at the European level. Detailed registration and evaluation of streambank vegetation isn't solved in this Act. This is the reason for the methodology of evaluation of stream-bank vegetation.

In Europe, the issue of stream-bank vegetation and stream buffer zones was published in works by Bache and Macaskill (1981) and Coroi, Skeffington and Giller (2004). The issue of floodplain forests of Europe was described for example by Klimo et al. (2008). In North America and Australia, stream-bank vegetation assessment was mostly solved in connection with the river assessment or with the bank stability evaluation. River and streambank assessment was solved for example in works by Patterson (1976), Roth, Allan and Erickson (1996), Parsons, Thomas and Norris (2000) and Burton, Smith and Cowley (2008). The stability effect of the vegetation to the riverbanks and the bank stability were solved by Geyer, Nepple and Brooks (1993), Shields (1991) and Abernethy and Rutherfurd (2000). Stream restoration evaluation assessment form was prepared by NCSU Water Quality Group ${ }^{3}$.

In the Czech Republic the unified methodology of stream-bank vegetation assessment is not available at present (Havlíčková, 2005). Streamside stands management was dealt with by Šlezingr and Úradníček (2002, 2003), Havlíčková (2005), Marhoun (1982), Novák, Iblová and Škopek (1986) and Erlich (1992). River evaluation, including stream-bank vegetation evaluation was dealt with by Fuksa (2001) and by Demek (2006). Streamside stands registration was dealt with in special management plans (for example Mařák, 1996). Plans were projected for some rivers in administration of Povodí Moravy, s.p. Applied methodology has not been published yet. Special management plans for the Bystřička stream (hydrology order 4-13-01-123) and Salaška stream (hydrology order 4-13-01-082) serve as the basis for this article (methodology). Management plans consist of river basin and streamside stand evaluation and management proposal.

Many streamside stands are not in good condition at present. Some stands are formed by exotic species or by species unsuitable for the site. Many streamside stands are discontinuous; some banks of small streams are without woody vegetation. The reason for this is, among others, the absence of a unified stream-bank vegetation register and of management planning.

\footnotetext{
2 Land Development Manual (2004), policy 22: Stream buffer zone. Retrieved from: http://www.cityofknoxville.org/engineering/ldmanual/LD-EP22.pdf

3 NCSU Water Quality Group. (2006). Stream restoration evaluation assessment form. Retrieved from: http://www.bae.ncsu.edu/programs/extension/wqg/sri/cwmtf/Assessment\%20Form.pdf
} 
This article presents the methodology for stream-bank vegetation evaluation. This methodology is aimed for registration and evaluation of streamside stands in rural landscapes. In the conclusion the management proposal is presented. The knowledge of hydrology, geobiocenology, dendrology, tree measuring, tree assessment and geoinformation technologies are applied in the methodology.

\section{Materials and methods}

The Presented methodology is applicable for evaluation of stream-bank vegetation. Assessed vegetation (stands) is evaluated on the basis of spatial characteristics, structure, species composition and vitality. The goal of the methodology is to elaborate the stream-bank vegetation database, which serves as the basis for the special management plan.

\subsection{Locality}

The methodology is applied to the example of registration and evaluation of stream-bank vegetation in section of the Rakovec river (hydrology order 4-15-03-069). Rakovec is the right tributary of the Litava river. A spring is located under the hill called Lipový kopec (561 $\mathrm{m}$, spring elevation - $485 \mathrm{~m}$ ) and river mouth is close to the village called Hrušky, elevation $-200 \mathrm{~m}^{4}$.

The survey section is located in the eastern part of the South Moravian Region (division Vyškov). This section is limited by the river mouth (river log: $0.0 \mathrm{~km}$ ) and highway D1 (river log: $8.95 \mathrm{~km}$, elevation $225 \mathrm{~m}$ ). Particular results (maps and databases) are presented on example of section 10 (river log: 4.865-5.575 km), which is located close to the Holubice village.

The flood plain in the survey area is intensively utilized. The following chart shows use of the land close to the evaluated sections. Most of the area (73.6\%) is utilized as arable land, $11.2 \%$ of banks border is formed by the road or built up area. $15.1 \%$ of stream-bank vegetation borders on forest or perennial vegetation (forest, garden, grassland).

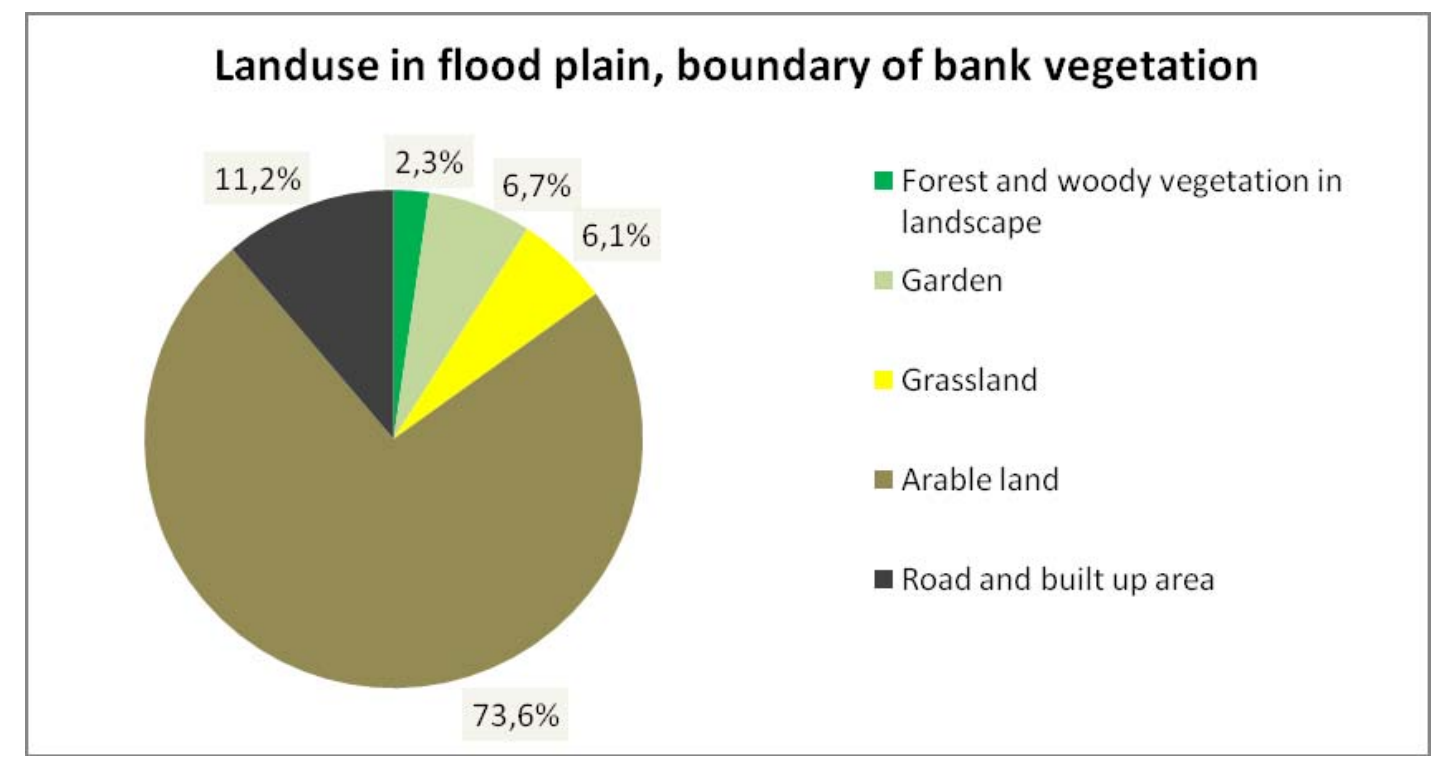

Fig 1. Land Use in flood plain of evaluated sections

\subsection{Principles of proposed (designed) methodology}

Evaluating stream-bank vegetation consists of the respective procedure steps: preliminary work, surveying and stream-bank vegetation evaluation, data processing and management.

Evaluated rivers (parts of the rivers) are divided into sections, separated by natural or artificial barriers (bridge, object on the river, etc). Barriers $10 \mathrm{~m}$ wide or more are excluded from the evaluation. Assessed sections are limited by the borders of the barrier (for example road

\footnotetext{
${ }^{4}$ cenia_dmu25 Retrieved from http://geoportal.cenia.cz
} 
border). Barriers narrower than $10 \mathrm{~m}$ are included in the assessed sections. The border is defined as a barrier centreline.

Within the sections, the segments are determined. Segments are vegetation parts of the sections with similar characteristics (width, structure, species composition, etc.). Minimal segment length is $50 \mathrm{~m}$, shorter segments are united or distinguished as sub-segments. Shorter segments with similar characteristics can be merged into the mosaic.

The relationship between left and right banks depends on the river type. 3 river types are defined for the presented methodology. The river types are based on Strahler stream order ${ }^{5} .1^{\text {st }}$ type includes brooks ( $1^{\text {st }}$ and $2^{\text {nd }}$ Strahler stream order). Left and right banks are evaluated together. Possible differences are mentioned in notes of the database. $2^{\text {nd }}$ type includes streams and small rivers $\left(3^{\text {rd }}-5^{\text {th }}\right.$ Strahler stream order). Left and right banks are evaluated separately. Segments on left and right bank are defined dependently on one another. Segments of the left and right bank begin and end in the same river profile. Different stands in frame of the segments are distinguished as sub-segments. $3^{\text {rd }}$ type includes rivers $\left(6^{\text {th }}\right.$ and higher Strahler stream order). Left and right banks are evaluated separately. Segments of the left bank are evaluated independently of segments of the right bank.

\subsection{Section and segment characterization}

Sections are characterized by typology according to the Water Framework Directive (ecoregion, altitude typology and size typology) and by specification at the local (national) level (hydrological order, hydrological log of beginning and end of the sections, length, etc.)

Segments are characterized by spatial delimitation, flood plain and river-basin characteristics and by stream-bank vegetation. Segments are mapped as lines (segments wider than $50 \mathrm{~m}$ are mapped as polygons). Spatial delimitation of a segment is given by beginning and end river log, length (division between end and beginning river log), mid-width and area. Mid-width is defined by water level and external border of the stand or by a boundary of intensive land use (arable land, road, building up area, etc.). Width is measured in characteristic places and is given in meters. The area is the product of length and mid-width.

Flood plains are characterized by natural conditions, land use and by river-basin depth. Natural conditions are given by group of ecosystem type (GET) (Buček, Lacina, 2002) or by group of forest type (GFT). In this methodology Zlatník's classification system, modified by Šimíček (1999) was applied. System is displayed in the following table.

Rivers are characterized by a river-basin (natural or modified), stream bottom material, bank (inclination, bunding) and natural conditions.

Stream-bank vegetation (streamside stands) is characterized by width, spatial structure, species composition, physiological age and state of health. Species of trees reaching by their presentation at least $10 \%$ are objects of special measuring.

\subsection{Spatial structure of stream-bank vegetation}

The width of the vegetation zone is given in meters and width category is determined. In the presented methodology the modified Šlezingr's scale is applied. Width category depends on width, number of lines, and space dislocation. The $1^{\text {st }}$ category includes narrow line stands, $2^{\text {nd }}$ category comprises line stands of grown trees and shrubs. Multiline or planar stands (width less than $10 \mathrm{~m}$ ) are classed to the $3^{\text {rd }}$ category. Planar stands, wider than 10 meters, are classified to the $4^{\text {th }}$ width category.

Spatial structure is characterized by the number of vegetation layers and by stream-bank vegetation continuity (relative density of stand). Vegetation layers are distinguished by dendrometric characteristics, especially by height. The required continuity of the layer is $30 \%$ and more and the individual layers should have the common projection. For example a mosaic of tree and shrubs particular segments, without shared protection is classified as 1 storey stand.

\footnotetext{
${ }^{5}$ Strahler number, from Wikipedia, the free encyclopedia. Retrieved from: http://en.wikipedia.org/wiki/Strahler_number
} 


\begin{tabular}{|c|c|c|c|c|c|c|c|c|c|c|}
\hline \multirow[b]{2}{*}{ 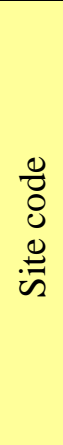 } & \multirow[b]{2}{*}{$\begin{array}{c}\text { Site name } \\
\text { (Zlatník, 1956) }\end{array}$} & \multirow[b]{2}{*}{ 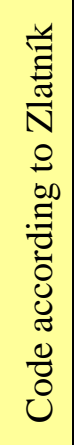 } & \multirow[b]{2}{*}{ 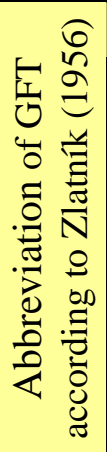 } & \multirow[b]{2}{*}{ 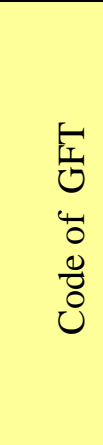 } & \multirow[b]{2}{*}{ 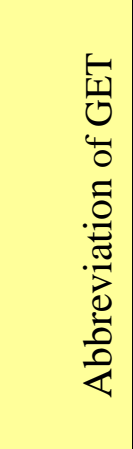 } & \multicolumn{3}{|c|}{ GET code } & \multicolumn{2}{|r|}{ Natura 2000} \\
\hline & & & & & & 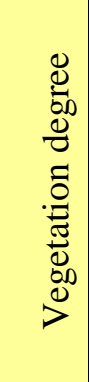 & 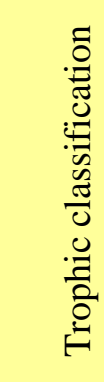 & 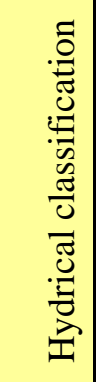 & סृ & name \\
\hline \multirow{2}{*}{1} & \multirow{2}{*}{$\begin{array}{l}\text { Willow } \\
\text { alderwoods }\end{array}$} & \multirow[b]{2}{*}{23} & \multirow[b]{2}{*}{ Sal } & \multirow{2}{*}{$1 \mathrm{G}$} & AlS inf & 2 & $\mathrm{BC}$ & $5 b$ & \multirow{2}{*}{ L2.4 } & \multirow{2}{*}{$\begin{array}{l}\text { Willow-poplar forests } \\
\text { of lowland rivers }\end{array}$} \\
\hline & & & & & Als sup & $2-3$ & $\mathrm{BC}$ & $5 b$ & & \\
\hline \multirow{2}{*}{2} & \multirow{2}{*}{ Oak ashwoods } & \multirow[b]{2}{*}{24} & \multirow[b]{2}{*}{ QFr } & \multirow{2}{*}{ 1L9 } & QFr inf & 2 & BC-C & (4) $5 \mathrm{a}$ & \multirow{2}{*}{ L2.3 } & \multirow{2}{*}{$\begin{array}{l}\text { Hardwood forests of } \\
\text { lowland rivers }\end{array}$} \\
\hline & & & & & QFr sup & $2-3$ & BC-C & (4) $5 \mathrm{a}$ & & \\
\hline \multirow{4}{*}{3} & \multirow{4}{*}{$\begin{array}{l}\text { Poplar-elm } \\
\text { ashwoods }\end{array}$} & \multirow[b]{4}{*}{25} & \multirow[b]{4}{*}{ Ufrp } & \multirow{4}{*}{$1 \mathrm{U}$} & Sa inf & 1 & $\mathrm{~B}-\mathrm{C}$ & $5 a$ & \multirow{2}{*}{$\mathrm{L} 2.4$} & \multirow{2}{*}{$\begin{array}{l}\text { Willow-poplar forests } \\
\text { of lowland rivers }\end{array}$} \\
\hline & & & & & Sa sup & 2 & $\mathrm{~B}-\mathrm{C}$ & $5 a$ & & \\
\hline & & & & & Ufrp inf & 2 & C & (4)5a & & \\
\hline & & & & & $\begin{array}{l}\text { Ufrp } \\
\text { sup }\end{array}$ & $2-3$ & C & (4) $5 \mathrm{a}$ & $\mathrm{L} 2.3$ & $\begin{array}{l}\text { Hardwood forests of } \\
\text { lowland rivers }\end{array}$ \\
\hline \multirow{3}{*}{4} & \multirow{3}{*}{$\begin{array}{l}\text { Hornbeam-elm } \\
\text { ashwoods, } \\
\text { elmwoods }\end{array}$} & \multirow[b]{3}{*}{25} & \multirow[b]{2}{*}{ Ufrc } & $1 \mathrm{~L}$ & Ufrc inf & 1 & BC-C & (3) 4 & \multirow[b]{3}{*}{$\mathrm{L} 2.3$} & \multirow{3}{*}{$\begin{array}{l}\text { Hardwood forests of } \\
\text { lowland rivers }\end{array}$} \\
\hline & & & & $\begin{array}{l}(1 \mathrm{U}) \\
2 \mathrm{~L}\end{array}$ & $\begin{array}{l}\text { Ufrc } \\
\text { sup }\end{array}$ & 2 & BC-C & (3) 4 & & \\
\hline & & & $\mathrm{U}$ & $1 \mathrm{~L}$ & $\mathrm{U}$ & \multirow[b]{2}{*}{$2-3$} & $\mathrm{D}$ & $4-5 b$ & & \\
\hline 5 & $\begin{array}{l}\text { Ash alderwoods } \\
\text { of lower zone }\end{array}$ & 26 & $\begin{array}{l}\text { FrAl } \\
\text { inf. }\end{array}$ & $\begin{array}{l}(2 \mathrm{~L}) \\
3 \mathrm{~L}\end{array}$ & $\mathrm{FrAl} \inf$ & & BC-C & (4) $5 \mathrm{a}$ & $\mathrm{L} 2.2$ & $\begin{array}{l}\text { Ash-alder alluvial } \\
\text { forests }\end{array}$ \\
\hline 6 & $\begin{array}{l}\text { Ash alderwoods } \\
\text { of upper zone }\end{array}$ & 26 & $\begin{array}{l}\text { FrAl } \\
\text { sup. }\end{array}$ & $\begin{array}{l}(3 \mathrm{~L}) \\
5 \mathrm{~L}\end{array}$ & $\begin{array}{l}\text { FrAl } \\
\text { sup }\end{array}$ & $4-5$ & BC-C & (4)5a & L2.2 & $\begin{array}{l}\text { Ash-alder alluvial } \\
\text { forests }\end{array}$ \\
\hline 7 & $\begin{array}{l}\text { Alderwoods of } \\
\text { grey alder }\end{array}$ & 27 & Ali & $6 \mathrm{~L}$ & Ali & 6 & BC-C & $5 a$ & L2.1 & $\begin{array}{l}\text { Montane grey alder } \\
\text { galleries }\end{array}$ \\
\hline
\end{tabular}

Tab 1. Characterization of Flood Plain

Stream-bank vegetation (layer) continuity (canopy closure or relative density) means coverage of area by treetop projection. Continuity is evaluated for tree layer, shrub layer and for streambank vegetation (total). In the case of the stream-bank vegetation, continuity is the share of bank with woody vegetation. In the case of the layers, continuity is the share of the bank with layer (tree layer, or shrub layer). Continuity is given as decimal number from 0.0 (without stand or layer) to 1.0 (continuous stand or layer without interspaces). 5 classes are defined on the basis of continuity:
1) $0.0 \quad-$ without woody plant
2) $0.1-0.3$ - solitaire woody plants (trees or shrubs)
3) $0.4-0.6$ - layer (stand) with interspaces in canopy (broken canopy)
4) $0.7-0.8$ - layer (stand) with open canopy
5) $0.9-1.0$ - continuous layer (stand)

\subsection{Species composition and structure}

Species composition is an important characteristic. Tree and shrub layers are evaluated separately and herbal species are registered. Species composition (representation) is given by decimal number $(0.1-1.0)$. The species with a representation of less than $10 \%$ are registered without a representation value and they are marked by + in the database.

The current species composition is compared with potential composition according to Zlatník (Šimíček, 1997). The following table states the maximum share of the species in potential composition. The share is displayed by decimal number from 0 to 1 ( 1 responds to $100 \%$ ). Upper limit of accessory species is determined as $0.1(10 \%)$. 
The degree of species composition autochtonity (degree of autochtonity) is the sum of the partial values of the species. Partial values of the species are given by current and by natural share of species. In the event that the current species representation exceeds the maximum potential representation, the partial value of species is given by the maximum potential value. In the event that the current species representation does not exceed the maximum potential representation, the partial value of species is given by the current species representation. Degree of autochtonity can reach values from 0 to 1 (from $0 \%$ to $100 \%$ ). Method of calculation is demonstrated on the following example:

Site: FrAl inf. (Ash alder woods of lower zone):

$\mathrm{OL} \quad$ - maximum potential representation: 0.8; current representation 0.4 (40\%)

VR - maximum potential representation: 0.3; current representation $0.4(40 \%)$

TPS - maximum potential representation: 0.0; current representation $0.2(20 \%)$

\begin{tabular}{|c|c|c|c|c|c|c|c|c|c|c|}
\hline \multirow{3}{*}{ 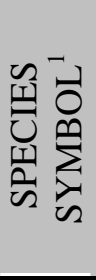 } & \multirow{3}{*}{$\begin{array}{l}\text { ENGLISH } \\
\text { NAME }^{2} \\
\end{array}$} & \multirow[b]{3}{*}{ SCIENTIFIC NAME $^{1}$} & \multirow{3}{*}{ 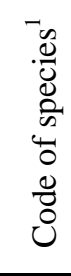 } & \multicolumn{7}{|c|}{ Site type according to Zlatník (1956) } \\
\hline & & & & Sal & QFr & Ufrp & Ufrc & $\begin{array}{c}\text { FrAl } \\
\text { inf. }\end{array}$ & \begin{tabular}{|l|} 
FrAl \\
sup.
\end{tabular} & Ali \\
\hline & & & & 1 & 2 & 3 & 4 & 5 & \begin{tabular}{|l|l}
6 \\
\end{tabular} & 7 \\
\hline DB & $\begin{array}{l}\text { Penduculate } \\
\text { oak }\end{array}$ & Quercus robur L. & 40 & 0.1 & 0.8 & 0.6 & 0.7 & 0.3 & 0.1 & 0.1 \\
\hline JVJ & Boxelder & Acer negundo L. & 55 & $\mathbf{0}$ & $\mathbf{0}$ & $\mathbf{0}$ & $\mathbf{0}$ & $\mathbf{0}$ & $\mathbf{0}$ & $\mathbf{0}$ \\
\hline JS & Common ash & Fraxinus excelsior L. & 57 & 0.1 & 0.4 & 0.4 & 0.3 & 0.6 & 0.6 & 0.1 \\
\hline $\mathrm{AK}$ & Black locust & Robinia pseudacacia L. & 63 & $\mathbf{0}$ & $\mathbf{0}$ & 0 & 0 & $\mathbf{0}$ & $\mathbf{0}$ & $\mathbf{0}$ \\
\hline $\mathrm{OL}$ & Common alder & Alnus glutinosa L. & 83 & 0.8 & 0.1 & 0.1 & 0.1 & 0.8 & 0.8 & 0.3 \\
\hline OLS & Grey alder & Alnus incana L. & 84 & 0.1 & 0.1 & 0.1 & 0.1 & 0.1 & 0.1 & 1 \\
\hline TPS & Hybrid poplar & $\begin{array}{l}\text { Populus x canadensis } \\
\text { Moench. }\end{array}$ & 90 & $\mathbf{0}$ & $\mathbf{0}$ & $\mathbf{0}$ & $\mathbf{0}$ & $\mathbf{0}$ & $\mathbf{0}$ & $\mathbf{0}$ \\
\hline VR & $\begin{array}{l}\text { White willow, } \\
\text { Crack willow }\end{array}$ & $\begin{array}{l}\text { Salix alba L., Salix } \\
\text { fragilis L. }\end{array}$ & 92 & 0.6 & 0.1 & 0.1 & 0.1 & 0.3 & 0.3 & 0.3 \\
\hline
\end{tabular}

Tab 2. Maximum Potential Species Representation, complete table is in Appendix No. 1

${ }^{1}$ symbol and code of the species and scientific name: according to Appendix No. 4 to Decree No. 84/1996Coll. on Forest Management Planning.

${ }^{2}$ English names according to Šlezingr, Úradníček (2003)

In the case of $\mathrm{OL}$, the maximum potential representation is not exceeded, thus the partial value is given by the current representation (0.4). In the case of VR a TPS, the maximum potential representation is exceeded, the partial values of species are given by the maximum potential representation (VR - 0.3, TPS - 0).

$$
\begin{aligned}
& A U T_{P O R}=P V_{S P E C 1} P V_{S P E C 2}+P V_{S P E C N} \\
& A U T_{P O R}=P V_{O L}+P V_{V R}+P V_{T P S} \\
& A U T_{P O R}=0.4+0.3+0 \\
& A U T_{P O R}=0.7 \\
& A U T_{P O R}-\text { degree of storey species composition autochtonity, range: } 0-1 \\
& P V_{S P E C 1-N} \text { - partial value of the species }
\end{aligned}
$$




\begin{tabular}{|l|c|c|c|c|}
\hline \multicolumn{1}{|c|}{ Characteristics of immixing } & \multicolumn{3}{c|}{ Form of the immixing } \\
\hline \multicolumn{1}{|c|}{ Characteristics } & Code & S & \multicolumn{1}{c|}{ G } & L (A) \\
\hline monocultures & C & \multicolumn{3}{c|}{0} \\
\hline stands with accessory species & CA $_{S}$ & 1 & 0 & 0 \\
\hline stands with dominant species & DP & 2 & 1 & 0 \\
\hline stands with majority species, composed of 2 species & MZ & 3 & 2 & 1 \\
\hline $\begin{array}{l}\text { stands with majority species, composed of 3 and more } \\
\text { species }\end{array}$ & MZ, MPP & 4 & 3 & 2 \\
\hline stands composed of 3 species, without majority species & ZZZ, ZZP, ZPP & 5 & 4 & 3 \\
\hline $\begin{array}{l}\text { stands composed of 4 and more species, without } \\
\text { majority species }\end{array}$ & $\begin{array}{c}\text { ZZPP, ZPPP, } \\
\text { PPPP, etc. }\end{array}$ & 6 & 5 & 4 \\
\hline
\end{tabular}

Tab 3. Degree of Species Diversity of Tree Storey, Modified Table According to Vyskot et all. (2003)

Legend:

C - species with proportion of more than $90 \%$

$D$ - dominant species with proportion of $71-90 \%$

$M-$ majority species with proportion of $51-70 \%$

$Z$ - basic species with proportion of $31-50 \%$

$P$ - admixed or accessory species with proportion of $10-30 \%$

$A_{S}$ - accessory species with proportion of less than $10 \%)$

$S$ - single immixing

$G$ - group immixing

$L(A)$ - line or area immixing (depending up width of the segment)

In species diversity the accessing number and share of the species and form of the immixing (single, group or line) is evaluated. The degree of species diversity is interpreted in the following table.

\subsection{Development phase and vitality}

Physiological age (stage of development) is the development phase of the tree (stand, storey). A tree is evaluated according to Kolařík (2005). For comparison the graduated scale according to Vyskot (2003) is add.

\begin{tabular}{|c|c|c|c|c|}
\hline $\begin{array}{l}\text { Age } \\
\text { class } \\
\text { of } \\
\text { storey }\end{array}$ & $\begin{array}{c}\text { Age } \\
\text { degree } \\
\text { of tree }\end{array}$ & $\begin{array}{l}\text { Characteristics according } \\
\text { to Kolařík (2005) }\end{array}$ & $\begin{array}{c}\text { Characteristics according to } \\
\text { Vyskot (2003) }\end{array}$ & $\begin{array}{l}\text { Age in } \% \\
\text { rotation }\end{array}$ \\
\hline \multirow{5}{*}{1} & \multirow{2}{*}{1} & \multirow{2}{*}{ Non-established young tree } & Non-established young plantation, & \multirow{2}{*}{$\leq 7$} \\
\hline & & & regeneration & \\
\hline & \multirow{3}{*}{2} & \multirow{3}{*}{$\begin{array}{l}\text { Young tree in dynamical } \\
\text { grow phase }\end{array}$} & $\begin{array}{l}\text { Established young plantation, young } \\
\text { growth }\end{array}$ & $8-15$ \\
\hline & & & Small pole stage & $16-25$ \\
\hline & & & Pole stage & $26-40$ \\
\hline \multirow[t]{2}{*}{2} & \multirow[t]{2}{*}{3} & \multirow[t]{2}{*}{ Maturing tree } & $\begin{array}{l}\text { Large-diameter stand (of smaller } \\
\text { dimensions) }\end{array}$ & $41-60$ \\
\hline & & & Large-diameter stand (layers) & $61-80$ \\
\hline 3 & 4 & Mature tree & Mature stands (layers) & $80+$ \\
\hline
\end{tabular}

Tab 4. Stage of Development

Depending on physiological age and age diversity, 6 classes are distinguished. The $1^{\text {st }}$ class includes homogenous young stands (age degree of tree is 1 or 2 ). The $2^{\text {nd }}$ class includes homogenous maturing stands (storeys), consisting of trees in the $3^{\text {rd }}$ age degree. Homogenous mature stands (storeys) are in the $3^{\text {rd }}$ class and homogenous old stands (storeys) are in the $4^{\text {th }}$ class. Stands diversified by age are classified in the $5^{\text {th }}$ and $6^{\text {th }}$ age class. The $5^{\text {th }}$ class includes young stands (most of the trees are in the $1^{\text {st }}-3^{\text {rd }}$ degree) and the $6^{\text {th }}$ class includes old stands (most of the trees are in the $4^{\text {th }}-6^{\text {th }}$ degree). 
Physiological and biomechanical vitality of trees are assessed visually. Physiological vitality is the ability to resist harmful effects. Main symptoms of downgraded vitality are defoliation (lost leaves), branch malformation, crown drying-up, and secondary sprouts. Biomechanical vitality is the grade of mechanical damage and weakening. Biomechanical vitality is affected by habitual defects and by damages. Habitual defects have origins in tree growth, and include unsuitable high-diameter ratio (to thin stem), press branching, secondary sprouts and eccentric crown. Damage is caused by harmful effects. Damage includes cavities (open or close), wood cracks reaction wood and root system damages.

Physiological and biomechanical vitality are determined for species with representation of $10 \%$ and more. A scale from 1 to 5 is applied (1 means the best score, and 5 means the worst score). Tree total vitality is average of physiological and biomechanical vitality. Total stand (storey) vitality is the weighted arithmetic mean of total vitality of evaluated species. Weight is given by proportional share of species. Calculation of the vitality is demonstrated on the following example:

OL - share $50 \%$, biomechanical vitality 2 , physiological vitality 2, average: 2

VR - share $20 \%$, biomechanical vitality 4 , physiological vitality 3 , average: 3.5

TPS - share $30 \%$, biomechanical vitality 4 , physiological vitality 4 , average: 4

$\mathrm{VIT}_{\mathrm{ST}}=\mathrm{PROP}_{\text {spec } 1} \times \mathrm{VIT}_{\mathrm{SPEC} 1}+\mathrm{PROP}_{\text {spec } 2} \times \mathrm{VIT}_{\mathrm{SPEC} 2}+\ldots+\mathrm{PROP}_{\text {specN }} \times \mathrm{VIT}_{\text {SPECN }}$

$\mathrm{VIT}_{\mathrm{ST}}=\mathrm{PROP}_{\mathrm{OL} 1} \times \mathrm{VIT}_{\mathrm{OL}}+\mathrm{PROP}_{\mathrm{VR}} \times \mathrm{VIT}_{\mathrm{VR}}+\mathrm{PROP}_{\mathrm{TPS}} \times \mathrm{VIT}_{\mathrm{TPS}}$

$\mathrm{VIT}_{\mathrm{ST}}=0.5 \times 2+0.2 \times 3.5+0.3 \times 4$

$\underline{V I T} \underline{S T}=3.1$

VIT ST - total stand (storey) vitality, values from 1 to 5 .

$\mathrm{VIT}_{\text {spec1-n }}$ - total vitality of species (average of physiological and biomechanical vitality)

$\mathrm{PROP}_{\text {spec1-n }}$ - proportional share of species (decimal number from 0.1 to $1.0 ; 1.0$ corresponds to proportional share $100 \%$ )

Total vitality degree may be 1 to 5 . Stands can be classified to 3 classes:

$1^{\text {st }}$ class - vital stands (degree of stand vitality $1-2.3$ )

$2^{\text {nd }}$ class - slightly damaged stands (vitality $2.3-3.6$ )

$3^{\text {rd }}$ class - damaged stands (vitality $3.7-5$ ).

\subsection{Tree measuring}

Species in the tree layer, represented at least by $10 \%$, are objects of special measurement. Tree height and breast height diameter are measured; number of trees and number of stems per 100 meters of bank are quantified. Stem diameter (or perimeter) is usually measured in breast height $(130 \mathrm{~cm})$. It is measured by caliper or by diameter tape. Stems were measured twice across by caliper (with 1 meter range) and the average was counted. Thick stems (diameter more than 1 meter) were measured by tape. The diameter is given in centimeters (cm). Range of measurement depends on age and stand variability. In the case of young and homogenous stands, methods of sample line or sampler trees are applied. Whole layer measuring is suitable for mature or old stands (layers). The diameter is measured for trees reaching or exceeding the breast high diameter of $7 \mathrm{~cm}$. Tree height is the difference in elevation of terminal shoot and stem base. Height is usually measured by hypsometer, and it is given in meters. Height is measured by sampler trees. Sampler trees are selected for each species, which are the objects of special measurement.

\subsection{Databases and management theses}

The result of the methodology is the stream-bank vegetation database. The stream-bank vegetation database includes maps, databases, stream-bank vegetation evaluation and management theses. The connection of maps and databases are shown in the following diagram. Results of methodology are presented on example of section 10 of the evaluated Rakovec stream.

Management theses are proposed for segments (sub-segments). The goal of management depends on land use of a flood plain. In intensively utilized flood plain (arable land, road or build up area) stream-bank protection is usually preferred. The reason is the narrow space delimited to the rivers and banks (river zone). Shading of the water surface, water quality function, 
function of the bio-corridor and other functions of the vegetation are important too. In extensively utilized flood plains, with a wide river zone, re-establishing by processes, tending to natural floodplain ecosystem, is suitable.

Management theses apply silvicultural treatments, modified for line segment of stream-bank vegetation. Proposed treatments are distinguished according to urgency $(1-$ urgent, 2 - less urgent, 3 - not urgent). Depending on stand condition, the following treatments are proposed:

Planting: the aim is stand establishment. The treatment is proposed for banks without woody vegetation or for segments with solitaire trees. Repair planting (gapping): the goal is optimum canopy (continuity of stand) achievement. Gapping is proposed for stands with a broken canopy.

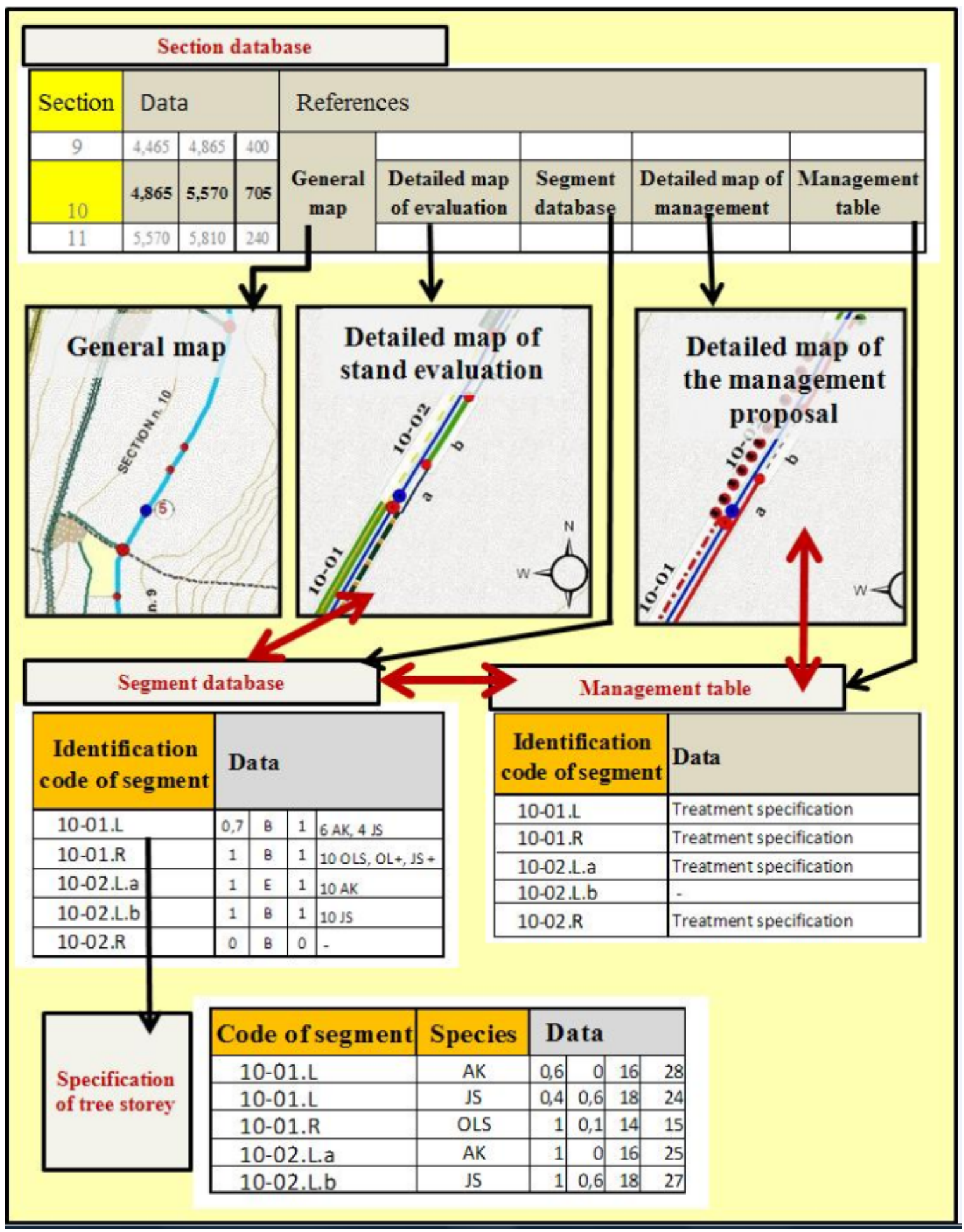

Fig 2. Diagram of Map-database Connection 
Regeneration: this treatment is proposed for mature or old stands. The goal of regeneration is renewing of the stand. Reconstruction is replacement of a young stand. The main reasons for reconstruction are unsuitable species composition and stand deterioration.

Stand tending: The aim of this treatment is achievement of good condition of young or maturing stands. Stand tending includes qualitative and species selection.

Treatments in shrub or herb layer (for example invasive species elimination).

\section{Results}

The results are presented by the stream-bank vegetation database on the example of section No. 10 and by summary of evaluated sections.

\subsection{Bank Vegetation Database}

The stream-bank vegetation database comprises maps and databases.

The map section includes general and detailed maps. The maps are generated by source maps (basic map, photomap) digitalization. Geographic information system (GIS software) is applied. The general maps show the evaluated stream and its division to sections and the land use. This map is shaped to display in 1:10 000 scale.

Detailed maps include a map of stand evaluation and a map of the management proposal. These maps consist of the line layers of streams and stream-bank vegetation (segments and sub-segments) and the point layers of segments delimitation and river log in kilometres. Detailed maps are connected with the respective databases and shaped to display in 1:2000 scale.

In the map of the evaluation, the individual segments (sub-segments) are displayed on the basis of stand continuity, width category, dominant storey and development phase (age class of the tree layer or height of shrub layer). In the map of the management proposal, the segments are displayed according to the designed treatment and treatment urgency. The maps are presented in Appendices (No. 2-6).

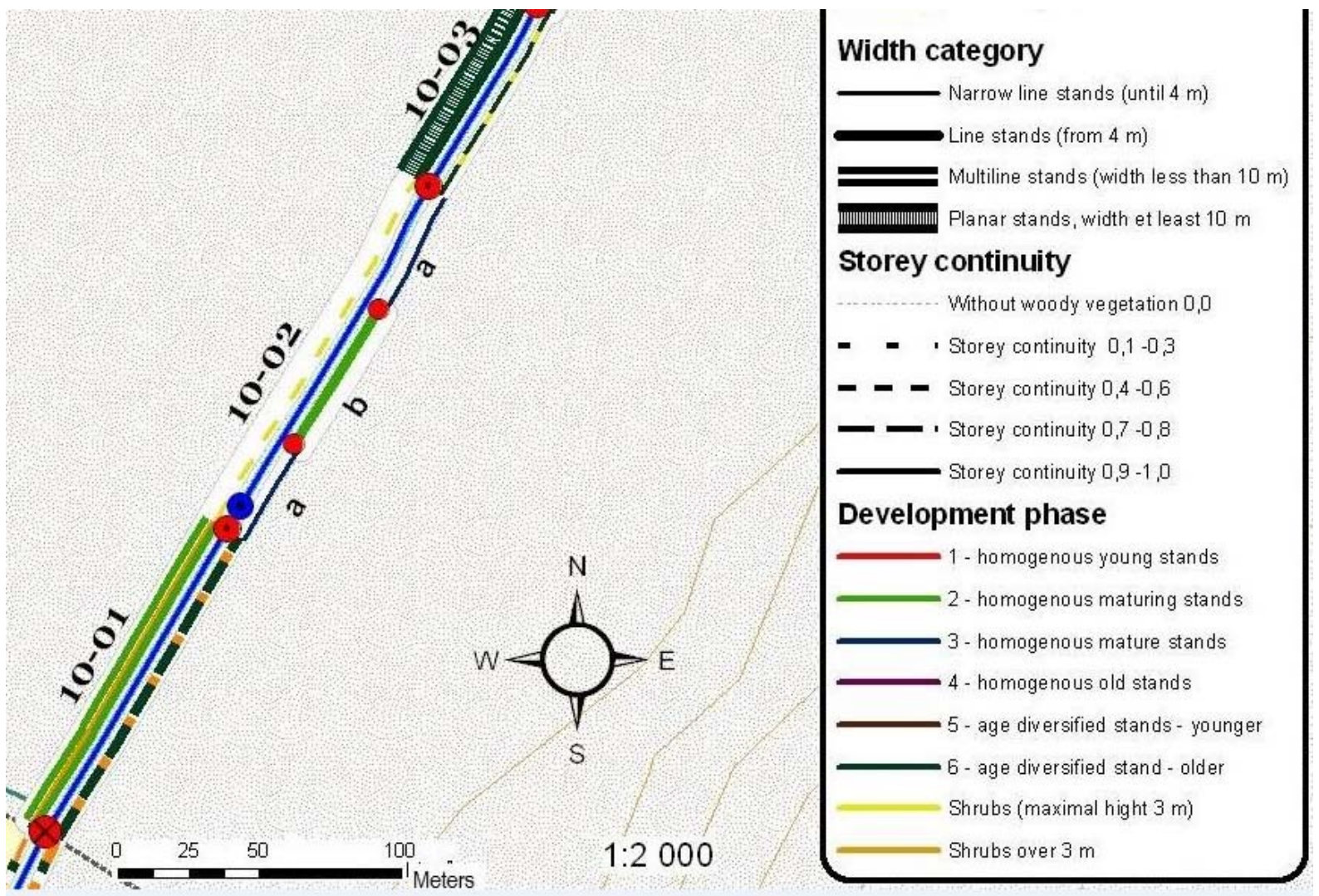

Fig 3. Example of Detailed Map of Stand Evaluation 
Databases consist of section database, segment database and specifications of tree layer. Subjects of section database are typology in the context of the Water Framework Directive (typology of water bodies), identification at the local level (section identification) and characterization of the stream. Typology of water bodies includes ecoregion, altitude typology (modified according to Langhammer et al, 2009) and size typology. Section identification is adapted to national or local conditions (national law, local or national evaluation methods, and existing databases). In the Czech Republic, section identification includes hydrological order, hydrological log of beginning and end of the sections. Sections (streams) are characterized by Strahler's order and length.

\begin{tabular}{|c|c|c|c|c|c|c|c|c|c|c|}
\hline \multirow[b]{2}{*}{ 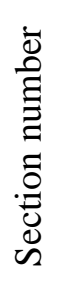 } & \multirow[b]{2}{*}{$\begin{array}{l}\text { Name of } \\
\text { stream }\end{array}$} & \multirow[b]{2}{*}{ 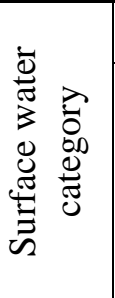 } & \multicolumn{3}{|c|}{ surface water body types } & \multirow[b]{2}{*}{$\begin{array}{l}\text { Hydrological } \\
\text { order }\end{array}$} & \multicolumn{2}{|c|}{ Hydrological log } & \multirow{2}{*}{ 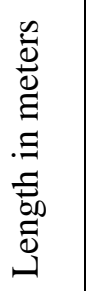 } & \multirow[b]{2}{*}{ 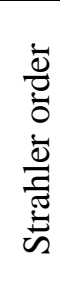 } \\
\hline & & & 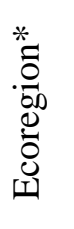 & 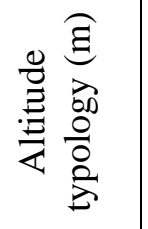 & 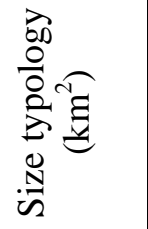 & & 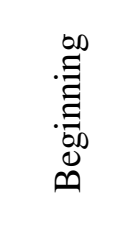 & 蔦 & & \\
\hline 9 & Rakovec & river & 11 & $\begin{array}{r}200- \\
500 \\
\end{array}$ & $\begin{array}{l}100- \\
1000\end{array}$ & $45-15-03-81$ & 4.465 & 4.865 & 400 & 5 \\
\hline 10 & Rakovec & river & 11 & $\begin{array}{r}200- \\
500\end{array}$ & $\begin{array}{l}100- \\
1000\end{array}$ & $45-15-03-81$ & 4.865 & 5.575 & 710 & 5 \\
\hline 11 & Rakovec & river & 11 & $\begin{array}{r}200- \\
500 \\
\end{array}$ & $\begin{array}{l}100- \\
1000\end{array}$ & $45-15-03-81$ & 5.575 & 5.815 & 240 & 5 \\
\hline
\end{tabular}

Tab 5. Section Database

* Hungarian lowlands (according to 2000/60, annex XI)

\begin{tabular}{|c|c|c|c|c|c|c|c|c|c|c|c|c|c|c|c|}
\hline 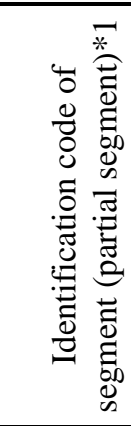 & 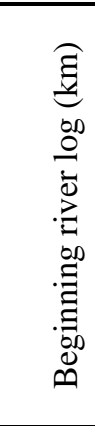 & 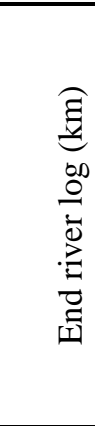 & 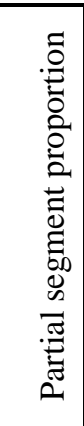 & 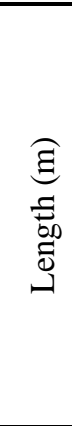 & 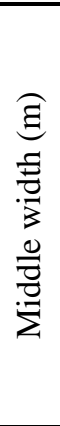 & 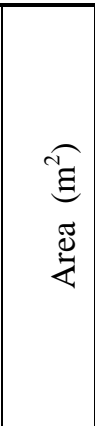 & 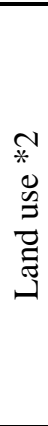 & 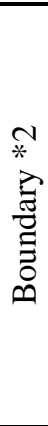 & 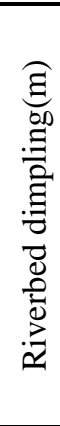 & 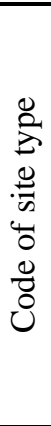 & 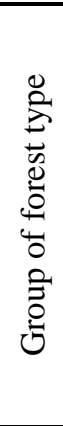 & 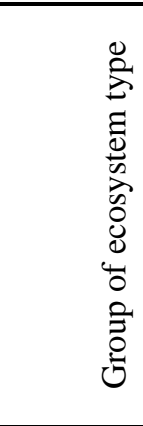 & 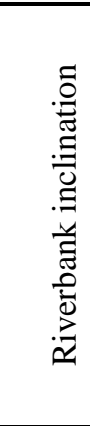 & 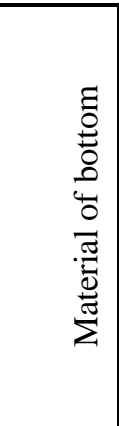 & 之ั \\
\hline 10-01.L & 4.865 & 4.99 & 1 & 125 & 6 & 750 & 5 & 5 & 2 & 5 & $2 \mathrm{~L}$ & FrAl inf. & $1: 2$ & gravel. & - \\
\hline 10-01.R & 4.865 & 4.99 & 1 & 125 & 9 & 1125 & 5 & 5 & 2 & 5 & $2 \mathrm{~L}$ & FrAl inf. & $1: 1$ & gravel. & channel-bed scour \\
\hline 10-02.L & 4.99 & 5.13 & & & & & & & & & & & & & \\
\hline $\begin{array}{l}\text { 10- } \\
\text { 02.L.a }\end{array}$ & & & 0.6 & 85 & 5 & 425 & 5 & 5 & 2 & 5 & $2 \mathrm{~L}$ & FrAl inf. & $1: 1$ & gravel. & channel-bed scour \\
\hline $\begin{array}{l}10- \\
\text { 02.L.b }\end{array}$ & & & 0.4 & 55 & 9 & 495 & 5 & 5 & 2 & 5 & $2 \mathrm{~L}$ & FrAl inf. & $1: 1.5$ & gravel. & 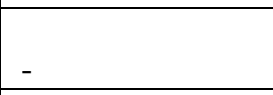 \\
\hline 10-02.R & 4.99 & 5.13 & 1 & 140 & 9 & 1260 & 5 & 5 & 2.5 & 5 & $2 \mathrm{~L}$ & FrAl inf. & $1: 1.5$ & gravel. & - \\
\hline 10-03.L & 5.13 & 5.205 & 1 & 75 & 5 & 375 & 5 & 5 & 2 & 5 & $2 \mathrm{~L}$ & FrAl inf. & $1: 1$ & gravel. & channel-bed scour \\
\hline 10-03.R & 5.13 & 5.205 & 1 & 75 & 13 & 975 & 5 & 5 & 2.5 & 5 & $2 \mathrm{~L}$ & FrAl inf. & $1: 1$ & gravel. & - \\
\hline 10-04.L & 5.205 & 5.575 & 1 & 370 & 7 & 2590 & 5 & 5 & 2 & 5 & $2 \mathrm{~L}$ & FrAl inf. & $1: 1$ & gravel. & - \\
\hline 10-04.R & 5.205 & 5.575 & & & & & & & & & & & & & \\
\hline $\begin{array}{l}\text { 10- } \\
\text { 04.R.a }\end{array}$ & & & 0.14 & 50 & 9 & 450 & 5 & 5 & 2 & 5 & $2 \mathrm{~L}$ & FrAl inf. & $1.5: 1$ & gravel. & channel-bed scour \\
\hline $\begin{array}{l}10- \\
04 . R . b\end{array}$ & & & 0.73 & 270 & 8 & 2160 & 5 & 5 & 2 & 5 & 2L & FrAl inf. & $1: 1$ & gravel. & - \\
\hline $\begin{array}{l}10- \\
\text { 04.R.c }\end{array}$ & & & 0.14 & 50 & 6 & 300 & 5 & 5 & 2 & 5 & $2 \mathrm{~L}$ & FrAl inf. & $1.5: 1$ & gravel. & channel-bed scour \\
\hline
\end{tabular}

Tab 6. Segment Database - Spatial Characteristics, Site and Stream Characteristics

1) $L$ - left bank, $R$ - right bank

2)2.1 CLC class: arable land 
The subjects of the segment database are identification, delimitation, flood plain and river-basin characteristics and stream-bank vegetation characteristics. Segments are identified according to the code. The code consists of section number, segment number, bank specification (left or right) and sub-segment specification (letter). Segment delimitation data include river log of the beginning and end of the segment, proportion share of partial segments, length, middle width and area. Subjects of flood plain data are potential and recent conditions, land use (Corine Land Cover classification) and river-basin depth. Stream data include bed material, information about bunding or scour erosion.

Object of stream-bank vegetation characteristic is description of the stand, tree layer and shrub layer. The database includes data about width category, continuity, qualitative rates (development phase, autochtonity, species diversity, etc.) and species composition. Species composition of tree layer is displayed as number $(1=10 \%, 2=20 \%-10=100 \%)$. Accessory species under $10 \%$ are displayed as + ). Representation of shrub layer species is displayed as letter ( $\mathrm{C}$ - species with a proportion of more than $90 \%$, D - dominant species, with a proportion of $71-90 \%, \mathrm{M}$ - majority species, with a proportion of $51-70 \%, \mathrm{Z}$ - species with a proportion of $31-50 \%, P$ - admixed species, with a proportion of $11-30 \%, A_{c}$ - accessory species, with a proportion of less than $10 \%$ ).

\begin{tabular}{|c|c|c|c|c|c|c|c|c|c|c|c|c|c|c|c|}
\hline \multirow[b]{2}{*}{ 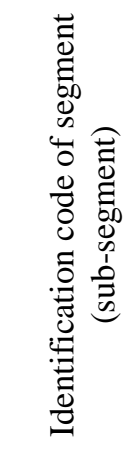 } & \multirow[b]{2}{*}{ 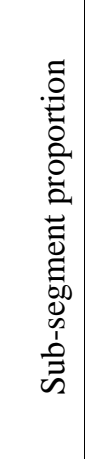 } & \multirow[b]{2}{*}{ 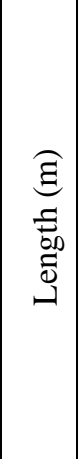 } & \multirow[b]{2}{*}{ 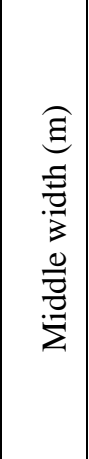 } & \multirow[b]{2}{*}{ 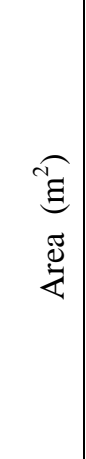 } & \multirow[b]{2}{*}{ 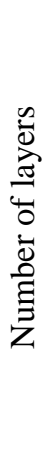 } & \multirow[b]{2}{*}{ 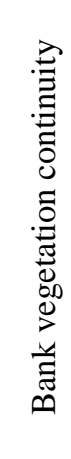 } & \multicolumn{9}{|c|}{ Tree layer } \\
\hline & & & & & & & 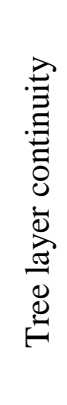 & 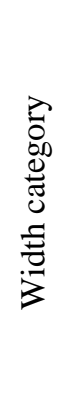 & 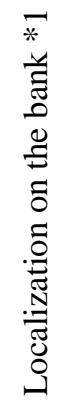 & 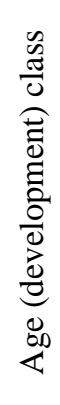 & 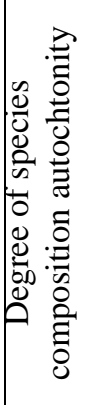 & 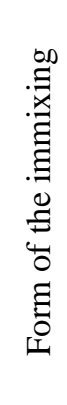 & 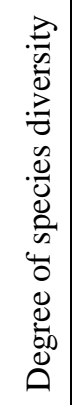 & & 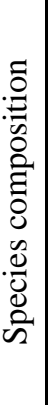 \\
\hline 10-01.L & 1.00 & 125 & 6.0 & 750 & 1 & 0.8 & 0.7 & 2 & B & 6 & 0.4 & $\mathrm{~L}$ & 1 & $6 \mathrm{AK}, 4 \mathrm{JS}$ & \\
\hline 10-01.R & 1.00 & 125 & 9.0 & $\begin{array}{r}1 \\
125 \\
\end{array}$ & 2 & 1.0 & 1.0 & 3 & B & 2 & 0.1 & $\mathrm{~J}$ & 1 & $10 \mathrm{OLS}, \mathrm{OL}+, \mathrm{JS}+$ & \\
\hline $\begin{array}{l}\text { 10- } \\
\text { 02.L.a }\end{array}$ & 0.60 & 85 & 5.0 & 425 & 1 & 1.0 & 1.0 & 1 & $\mathrm{E}$ & 3 & 0 & $\mathrm{M}$ & 0 & $10 \mathrm{AK}$ & \\
\hline $\begin{array}{l}10- \\
\text { 02.L.b }\end{array}$ & 0.40 & 55 & 9.0 & 495 & 2 & 1.0 & 1.0 & 2 & B & 2 & 0.6 & M & 0 & $10 \mathrm{JS}$ & \\
\hline 10-02.R & 1.00 & 140 & 9.0 & $\begin{array}{r}1 \\
260\end{array}$ & 1 & 0.6 & 0.0 & - & - & - & - & - & - & - & \\
\hline 10-03.L & 1.00 & 75 & 5.0 & 375 & 2 & 0.9 & 0.7 & 1 & B & 6 & 0.7 & $\mathrm{~J}$ & 5 & $5 \mathrm{JS}, 3 \mathrm{AK}, 2 \mathrm{OL}$ & \\
\hline 10-03.R & 1.00 & 75 & 13.0 & 975 & 3 & 1.0 & 1.0 & 4 & B & 6 & 0.65 & $\mathrm{~J}$ & 6 & $\begin{array}{l}4 \text { VR, } 2 \text { OL, } 1 \text { AK, } 1 \\
\text { TPS, } 1 \text { LP, } 1 \text { (JS, } \\
\text { JVJ), STH + }\end{array}$ & \\
\hline 10-04.L & 1.00 & 370 & 7.0 & $\begin{array}{r}2 \\
590 \\
\end{array}$ & 2 & 0.9 & 0.8 & 2 & B & 6 & 0.7 & $\mathrm{~J}$ & 3 & $7 \mathrm{JS}, 3 \mathrm{TP}$ & \\
\hline $\begin{array}{l}\text { 10- } \\
\text { 04.R.a }\end{array}$ & 0.14 & 50 & 9.0 & 450 & 2 & 1.0 & 1.0 & 3 & B & 4 & 0 & M & 0 & $10 \mathrm{AK}$ & \\
\hline $\begin{array}{l}\text { 10- } \\
\text { 04.R.b }\end{array}$ & 0.73 & 270 & 8.0 & $\begin{array}{r}2 \\
160 \\
\end{array}$ & 1 & 0.7 & 0.3 & 2 & B & 6 & 1 & $\mathrm{~J}$ & 3 & 7 JS, 2 OL, 1 VR & \\
\hline $\begin{array}{l}10- \\
\text { 04.R.c }\end{array}$ & 0.14 & 50 & 6.0 & 300 & 1 & 0.5 & 0.0 & - & - & - & - & - & - & - & \\
\hline
\end{tabular}

Tab 7. Segment Database - Database of Tree Layer (Tree Layer Characteristics)

${ }^{1}$ localization according to bank edge: $B$ - stands on the bank, E - stands on the bank edge, O - stands out of the bank

${ }^{2}$ species symbol according to Public Notice 83/96 Coll., Appendix No. 4 


\begin{tabular}{|c|c|c|c|c|c|c|c|c|c|c|c|c|}
\hline \multirow[b]{2}{*}{ 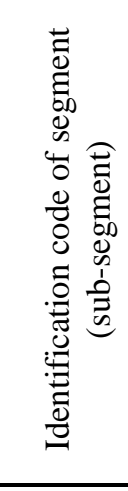 } & \multirow[b]{2}{*}{ 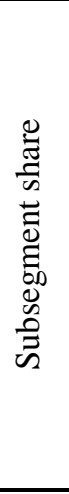 } & \multirow[b]{2}{*}{ 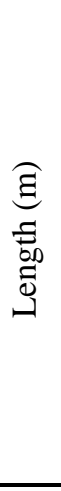 } & \multirow[b]{2}{*}{ 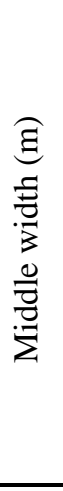 } & \multirow[b]{2}{*}{ 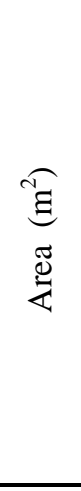 } & \multirow[b]{2}{*}{ 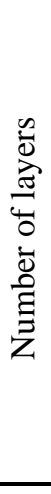 } & \multirow[b]{2}{*}{ 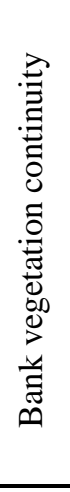 } & \multicolumn{6}{|c|}{ Shrub layer } \\
\hline & & & & & & & 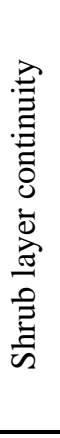 & 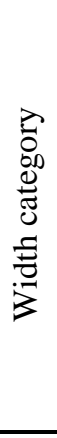 & 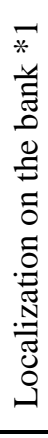 & 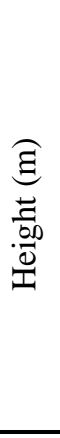 & 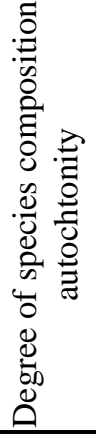 & 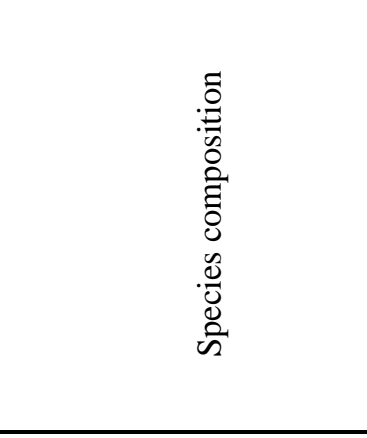 \\
\hline 10-01.L & 1.00 & 125 & 6.0 & 750 & 1 & 0.8 & 0.4 & 2 & $\mathrm{~B}$ & 4.0 & 0.4 & $\mathrm{AK} \mathrm{m}, \mathrm{BZC} \mathrm{z}$ \\
\hline 10-01.R & 1.00 & 125 & 9.0 & 1125 & 2 & 1.0 & 0.8 & 2 & $\mathrm{~B}$ & 3.5 & 1 & BZC d \\
\hline 10-02.L.a & 0.60 & 85 & 5.0 & 425 & 1 & 1.0 & 0.2 & 1 & $\mathrm{E}$ & 3.0 & 0.6 & $\mathrm{BZC} \mathrm{m}, \mathrm{AK} \mathrm{z}$ \\
\hline 10-02.L.b & 0.40 & 55 & 9.0 & 495 & 2 & 1.0 & 0.5 & 2 & $\mathrm{~B}$ & 3.0 & 0.6 & $\mathrm{BZC} \mathrm{m}, \mathrm{AK} \mathrm{z}$ \\
\hline 10-02.R & 1.00 & 140 & 9.0 & 1260 & 1 & 0.6 & 0.6 & 1 & $\mathrm{~B}$ & 3.0 & 1 & BZC d, TRN p \\
\hline 10-03.L & 1.00 & 75 & 5.0 & 375 & 2 & 0.9 & 0.5 & 1 & $\mathrm{~B}$ & 3.0 & 0.6 & $\mathrm{BZC} \mathrm{m}, \mathrm{AK} \mathrm{z}$ \\
\hline 10-03.R & 1.00 & 75 & 13.0 & 975 & 3 & 1.0 & 0.7 & 2 & $\mathrm{~B}$ & 4.0 & 0.6 & BZC z, JVJ z, JS p \\
\hline 10-04.L & 1.00 & 370 & 7.0 & 2590 & 2 & 0.9 & 0.6 & 2 & $\mathrm{~B}$ & 3.0 & 4 & BZC z, TRN z, JS p, BB,+ OR+ \\
\hline 10-04.R.a & 0.14 & 50 & 9.0 & 450 & 2 & 1.0 & 0.8 & 2 & $\mathrm{~B}$ & 3.0 & 0.6 & $\mathrm{BZC} \mathrm{m}, \mathrm{AK} \mathrm{z}$ \\
\hline 10-04.R.b & 0.73 & 270 & 8.0 & 2160 & 1 & 0.7 & 0.6 & 2 & $\mathrm{~B}$ & 4.0 & 1 & BZC z, TRN z, JS p, BB,+ OR+ \\
\hline 10-04.R.c & 0.14 & 50 & 6.0 & 300 & 1 & 0.5 & 0.5 & 1 & B & 3.0 & 1 & BZC m, TRN z \\
\hline
\end{tabular}

Tab 8. Segment Database - Database of Shrub Layer (Shrub Layer Characteristics)

${ }^{1}$ localization according to bank edge: $B$ - stands on the bank, E - stands on the bank edge, O - stands out of the bank

${ }^{2}$ species symbol according to (Ambros, Štykar, 1999)

The objects of specification of tree layer are the detailed data about tree stands. The specification is generated for tree layer with a continuity of at least $40 \%$ and for species with proportional share of at least $10 \%$. 


\begin{tabular}{|c|c|c|c|c|c|c|c|c|c|c|c|c|c|}
\hline 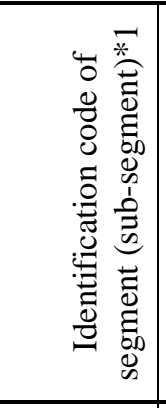 & 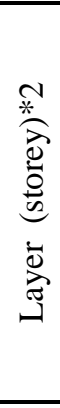 & 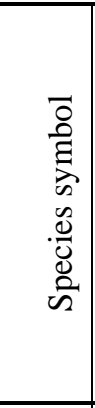 & 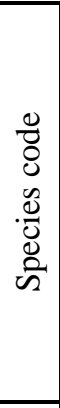 & 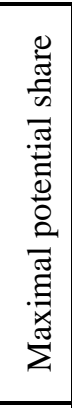 & 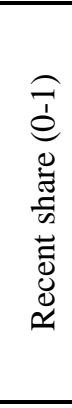 & 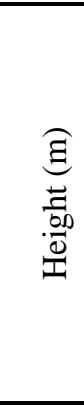 & 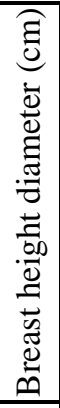 & 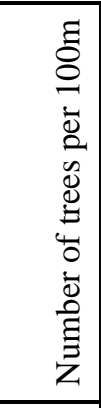 & 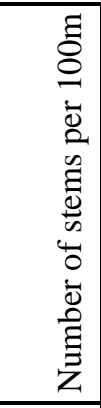 & 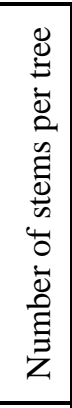 & 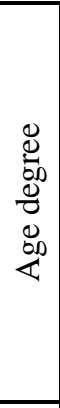 & 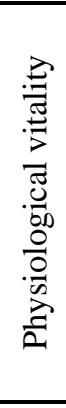 & 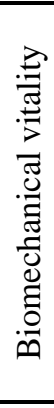 \\
\hline 10-01.L & $\mathrm{U}$ & AK & 55 & 0 & 0.6 & 16.0 & 28 & 18.4 & 23.2 & 1.3 & 4 & 3 & 4 \\
\hline 10-01.L & $\mathrm{U}$ & JS & 57 & 0.6 & 0.4 & 18.0 & 24 & 7.2 & 11.2 & 1.6 & 3 & 1 & 2 \\
\hline 10-01.R & $\mathrm{U}$ & OLS & 84 & 0.1 & 1.0 & 13.5 & 15 & 108.0 & 116.0 & 1.1 & 3 & 4 & 3 \\
\hline 10-02.L.a & $\mathrm{U}$ & $\mathrm{AK}$ & 55 & 0 & 1.0 & 15.5 & 25 & 36.7 & 51.1 & 1.4 & 4 & 4 & 5 \\
\hline 10-02.L.b & $\mathrm{U}$ & JS & 57 & 0.6 & 1.0 & 17.5 & 27 & 21.8 & 39.7 & 1.8 & 3 & 2 & 2 \\
\hline 10-03.L & $\mathrm{U}$ & JS & 57 & 0.6 & 0.5 & 22.0 & 34 & 9.3 & 9.3 & 1 & 3 & 2 & 2 \\
\hline 10-03.L & $\mathrm{U}$ & $\mathrm{AK}$ & 55 & 0 & 0.3 & 13.5 & 35 & 5.3 & 5.3 & 1 & 5 & 4 & 4 \\
\hline 10-03.L & $\mathrm{U}$ & OL & 83 & 0.8 & 0.2 & 20.0 & 41 & 2.7 & 5.3 & 2 & 4 & 2 & 2 \\
\hline 10-03.R & $\mathrm{U}$ & VR & 92 & 0.3 & 0.4 & 16.0 & 47 & 11.4 & 20.0 & 1.8 & 5 & 3 & 4 \\
\hline 10-03.R & $\mathrm{U}$ & $\mathrm{OL}$ & 83 & 0.8 & 0.2 & 18.5 & 26 & 7.1 & 10.0 & 1.4 & 3 & 2 & 2 \\
\hline 10-03.R & $\mathrm{U}$ & $\mathrm{AK}$ & 55 & 0 & 0.1 & 16.0 & 21 & 10.0 & 10.0 & 1 & 4 & 2 & 2 \\
\hline 10-03.R & $\mathrm{U}$ & TPS & 90 & 0 & 0.1 & 26.0 & 42 & 4.3 & 4.3 & 1 & 4 & 2 & 2 \\
\hline 10-03.R & $\mathrm{U}$ & LP & 80 & 0.3 & 0.1 & 16.0 & 23 & 2.9 & 11.4 & 4 & 3 & 2 & 2 \\
\hline 10-03.R & $\mathrm{L}$ & JS & 57 & 0.6 & 0.1 & 9.0 & 16 & 8.6 & 8.6 & 1 & 2 & 2 & 2 \\
\hline 10-03.R & $\mathrm{L}$ & JVJ & 55 & 0 & 0.1 & 8.0 & 16 & 8.6 & 8.6 & 1 & 2 & 2 & 2 \\
\hline 10-04.L & $\mathrm{U}$ & JS & 57 & 0.6 & 0.6 & 22.0 & 69 & 6.2 & 6.2 & 1 & 4 & 2 & 3 \\
\hline 10-04.L & $\mathrm{U}$ & TPS & 90 & 0 & 0.3 & 23.0 & 63 & 2.7 & 3.2 & 1.2 & 5 & 3 & 3 \\
\hline 10-04.L & $\mathrm{L}$ & JS & 57 & 0.6 & 0.1 & 12.0 & 21 & 4.3 & 5.1 & 1.2 & 2 & 1 & 1 \\
\hline 10-04.R.a & $\mathrm{U}$ & AK & 55 & 0 & 1.0 & 16.0 & 23 & 50.0 & 65.0 & 1.3 & 5 & 4 & 4 \\
\hline 10-04.R.b & $\mathrm{U}$ & JS & 57 & 0.6 & 0.5 & 23.0 & 46 & 1.5 & 1.5 & 1 & 4 & 2 & 2 \\
\hline 10-04.R.b & $\mathrm{U}$ & $\mathrm{OL}$ & 83 & 0.8 & 0.2 & 17.0 & 65 & 0.4 & 0.4 & 1 & 4 & 1 & 2 \\
\hline 10-04.R.b & $\mathrm{U}$ & VR & 92 & 0.3 & 0.1 & 22.0 & 47 & 0.4 & 0.4 & 1 & 5 & 3 & 4 \\
\hline 10-04.R.b & $\mathrm{L}$ & JS & 57 & 0.6 & 0.2 & 14.0 & 23 & 2.3 & 2.3 & 1 & 3 & 1 & 1 \\
\hline
\end{tabular}

Tab 9. Tree Layer Specification

1) U - upper storey (layer), $L$ - lower storey (layer)

2) species symbol according to (Ambros, Stykar, 1999) to Public Notice 83/96 Coll., Appendix No. 4

The database includes a table of management proposal. The object of the management table is the treatment specification and treatment urgency. 


\begin{tabular}{|c|c|c|c|c|c|c|c|c|c|c|c|}
\hline \multirow[b]{2}{*}{ 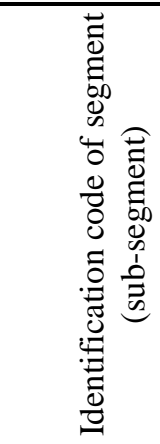 } & \multirow[b]{2}{*}{ 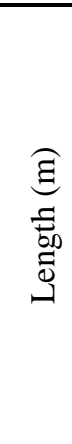 } & \multirow[b]{2}{*}{ 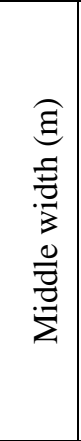 } & \multirow[b]{2}{*}{ 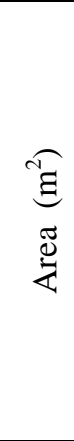 } & \multicolumn{7}{|c|}{ Treatment and urgency (1-3) } & \multirow[b]{2}{*}{ Treatment specification } \\
\hline & & & & 吕 & 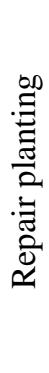 & 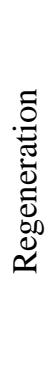 & 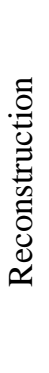 & 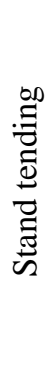 & 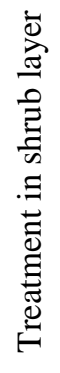 & 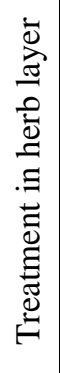 & \\
\hline 10-01.L & 125 & 6.0 & 750 & 0 & 0 & 1 & 0 & 0 & 0 & 0 & $\begin{array}{l}\text { Regeneration, planting of species suitable for } \\
\text { STG FrAl Inf. }\end{array}$ \\
\hline 10-01.R & 125 & 9.0 & $\begin{array}{r}1 \\
125\end{array}$ & 0 & 0 & 0 & 1 & 0 & 0 & 0 & $\begin{array}{l}\text { Reconstruction, planting of species suitable for } \\
\text { STG FrAl Inf. }\end{array}$ \\
\hline 10-02.L.a & 85 & 5.0 & 425 & 0 & 0 & 1 & 0 & 0 & 0 & 0 & $\begin{array}{l}\text { Regeneration, planting of species suitable for } \\
\text { STG FrAl Inf. }\end{array}$ \\
\hline 10-02.L.b & 55 & 9.0 & 495 & 0 & 0 & 0 & 0 & 0 & 0 & 0 & - \\
\hline 10-02.R & 140 & 9.0 & $\begin{array}{r}1 \\
260\end{array}$ & 1 & 0 & 0 & 0 & 0 & 0 & 0 & Planting of species suitable for STG FrAl Inf. \\
\hline 10-03.L & 75 & 5.0 & 375 & 0 & 3 & 0 & 0 & 1 & 0 & 0 & $\begin{array}{l}\text { Repair planting, vitality selection and unsuitable } \\
\text { species elimination }\end{array}$ \\
\hline 10-03.R & 75 & 13.0 & 975 & 0 & 0 & 0 & 0 & 3 & 0 & 0 & $\begin{array}{l}\text { Vitality selection and unsuitable species } \\
\text { elimination }\end{array}$ \\
\hline 10-04.L & 370 & 7.0 & $\begin{array}{r}2 \\
590\end{array}$ & 0 & 0 & 0 & 0 & 2 & 0 & 0 & $\begin{array}{l}\text { Vitality selection and unsuitable species } \\
\text { elimination }\end{array}$ \\
\hline 10-04.R.a & 50 & 9.0 & 450 & 0 & 0 & 1 & 0 & 0 & 0 & 0 & $\begin{array}{l}\text { Regeneration, planting of species suitable for } \\
\text { STG FrAl Inf. }\end{array}$ \\
\hline 10-04.R.b & 270 & 8.0 & $\begin{array}{r}2 \\
160\end{array}$ & 0 & 2 & 0 & 0 & 0 & 0 & 0 & Planting of species suitable for STG FrAl Inf. \\
\hline 10-04.R.c & 50 & 6.0 & 300 & 0 & 1 & 0 & 0 & 0 & 0 & 0 & Planting of species suitable for STG FrAl Inf. \\
\hline
\end{tabular}

Tab 10. Management Proposal Table

\subsection{Summary of Evaluated Section Data}

Stream-bank vegetation (streamside stands) is characterized by width, spatial structure, species composition, physiological age and state of health.

Width delimited for banks (width of vegetation zone) is displayed in the next diagram. 95\% of banks reach the width from 3 to 10 meters. Almost half $(47.1 \%)$ of the vegetation zone reach the width of $5.1-7 \mathrm{~m} .21 .9 \%$ of banks reach the width of less than $5 \mathrm{~m}$, and $31.1 \%$ of banks are wider than $7 \mathrm{~m}$.

Spatial structure is evaluated according to width, continuity of stream-bank vegetation and continuity of layers. The width is evaluated according to the width category. The $3^{\text {rd }}$ and the $4^{\text {th }}$ width categories merged and were termed as wide stands. In continuity evaluation the classes of continuity are applied (according to the methodology), the $4^{\text {th }}$ class (continuity $0.7-0.8$ ) and the $5^{\text {th }}$ class (continuity $0.9-1.0$ ) are merged.

Within the frame of evaluated sections, 13 basic types of structure are distinguished:

1. Wide continuous stands

2. Continuous tree line stands with shrub layer

3. Continuous tree line stands without shrub layer

4. Continuous narrow tree line stands

5. Continuous line stands with gaps in tree layer (discontinuous tree layer) and continuous shrub layer

6. Gappy (discontinuous) tree line stands

7. Continuous shrub line stands

8. Continuous narrow shrub line stands

9. Gappy (discontinuous) shrub line stands

10. Gappy (discontinuous) narrow shrub line stands 
11. Single trees and shrubs

12. Unclassified (for example stands behind the bank edge)

13. Without woody vegetation

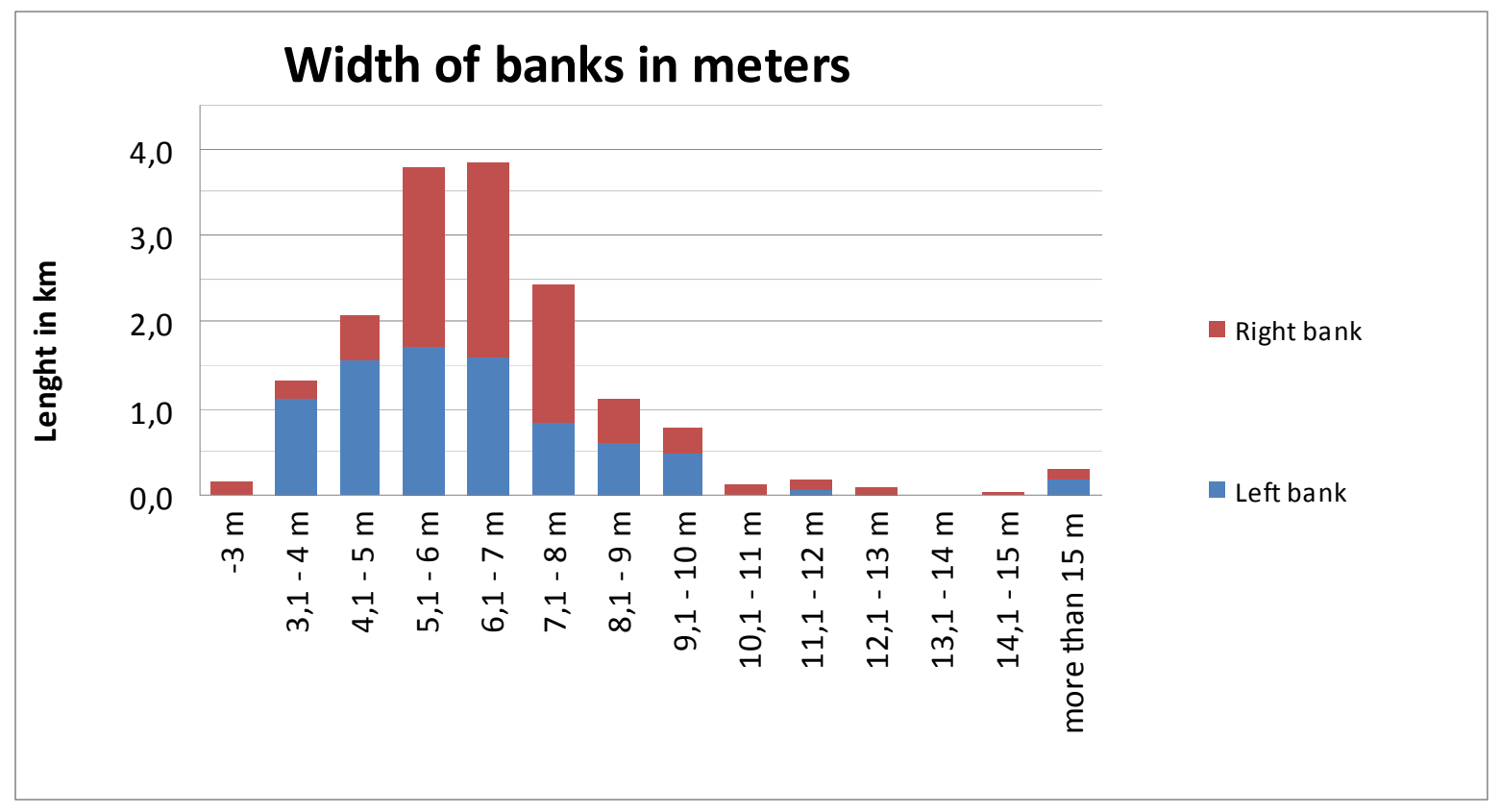

Fig 4. Bank Vegetation Width

Share of types is displayed in the following diagram:

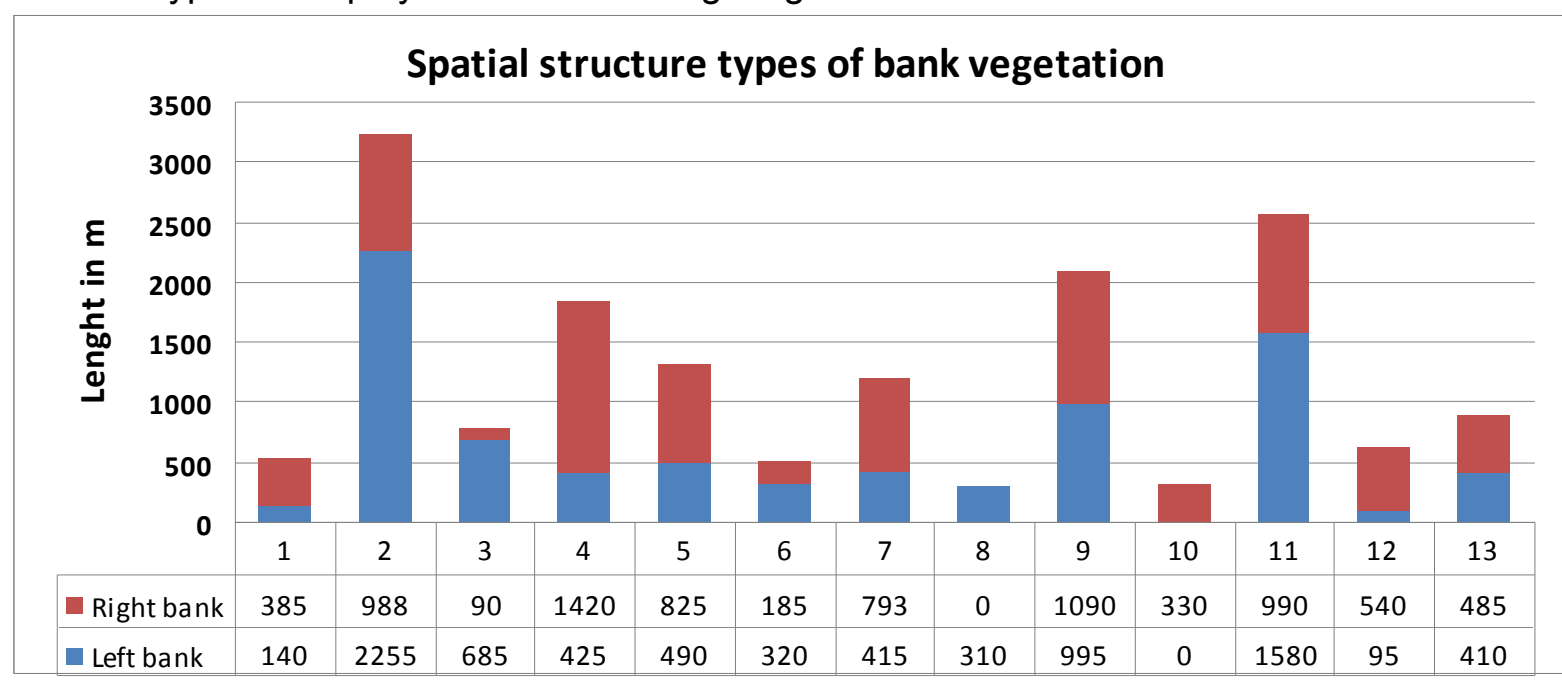

Fig 5. Bank Vegetation Spatial Structure

With regard to the functions of stream-bank vegetation, the continuous wide stand is the optimum structure type. Within the evaluated section, the proportional share of wide stand is $3.2 \%$ of length. In the intensively utilized landscape, the stream-bank vegetation is limited by boundary land use. Because of space limitation, a continuous line stand with shrub layer is a convenient structure type. The proportional share of this type is $20 \%$. The proportion of line tree stands without a shrub layer and (3) narrow tree line stand (4) is $16.1 \%$. Stands with discontinuous tree layer and shrub stands (categories 5-10) reached $35.4 \%$ of length of the evaluated sections. Banks with solitaires, banks without woody vegetation and unclassified types (11-13) reached $25.2 \%$ of length of the evaluated sections.

Species composition autochtonity and vitality of tree layer is evaluated in stands reaching the tree layer continuity of at least $0.4(40 \%)$. The length of evaluated segments is 8283 meters. Autochtonity is evaluated on the basis of degree of autochtonity (reached values from 0-1). 3 classes of species composition are determined: $1^{\text {st }}$ class- nature nearly stands (degree of 
autochtonity $0.7-1), 2^{\text {nd }}$ class- stands with modified composition (0.4-0.6) and $3^{\text {rd }}$ class allochthonous stands (0-0.3). In vitality evaluation, stands are classified to 3 classes, defined in methodology.

Depending on autochtonity and vitality 7 classes are determined ${ }^{1}$ :

1.1 Vital nature nearly stands

1.2 Slightly damaged nature nearly stands

2.1 Vital stands with modified composition

2.2 Slightly damaged stands with modified composition

3.1 Vital allochthonous stands

3.2 Slightly damaged allochthonous stands

3.3 Damaged allochthonous stands

The following diagram displays share of types:

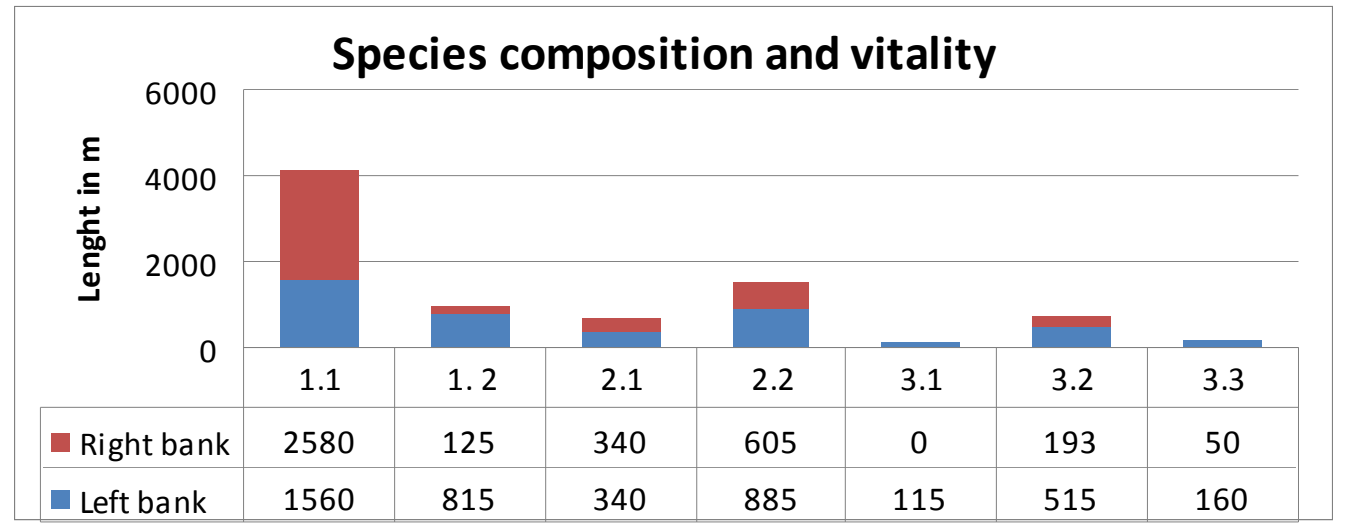

Fig 6. Autochtonity and Vitality of Tree Layer

$60 \%$ of evaluated tree layer is the $1^{\text {st }}$ class of species composition (nature nearly stands). Storey consists mainly of the autochthonous species: common alder (Alnus glutinosae L), European ash (Fraxinus excelsior L) and willows (Salix sp. L). $28 \%$ of evaluated tree layer is the $2^{\text {nd }}$ class of species composition (stands with modified composition) and $12 \%$ of evaluated tree layer is the $3^{\text {rd }}$ class of species composition (allochthonous stands). Allochthonous stands consist of alien or crossbred species, for example hybrid black poplars (Populus $x$ canadensis Moench) or black locus (Robinia pseudoacacia L). The main reasons for decreased vitality are hybrid poplar and black locus representation. In the case of autochthonous stands, old willow representation is the main reason of decreased vitality.

Species composition diversity is evaluated according to the methodology (degrees from 0 to 6 are applied). The results of species composition accession are displayed in the following diagram.

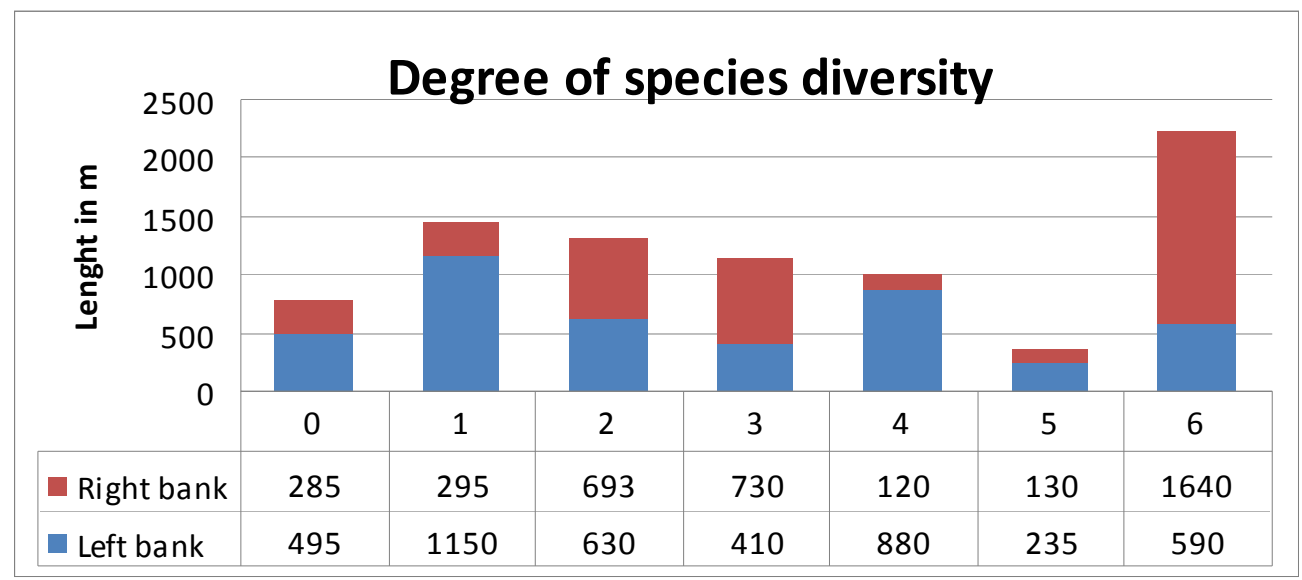

Fig 7. Diversity of Species Composition 
Homogenous tree layers or monocultures (degree of variability 0 or 1 ) reach $27 \%$ of length of the evaluated layers. The proportion of mixed stands (degree of variability $2-4$ ) reaches $42 \%$, and the share of heterogeneous storeys (degree of variability 5 or 6 ) reaches $31 \%$. High value of 6 degree proportion is caused by planting in section 13 and 14 .

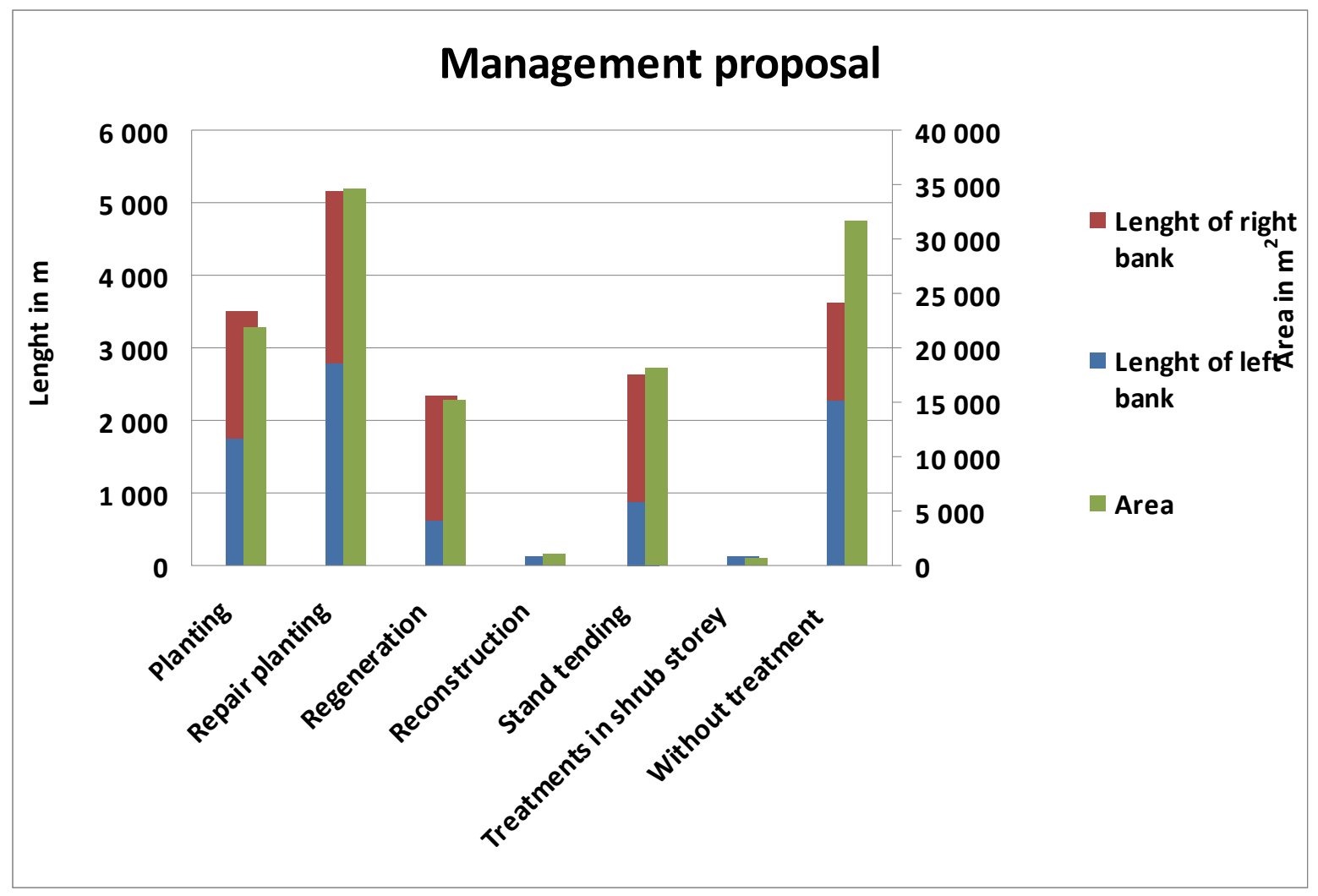

Fig 8. Management Proposal

The management proposal thesis depends on stand condition. Within the frame of the evaluated sections, planting is suitable treatment for $3.5 \mathrm{~km}$ of banks, repair planting is suitable for $5.17 \mathrm{~km}$. Reconstruction or regeneration is suitable treatment for $2.5 \mathrm{~km}$ of streamside stands, stand tending is proposed for $2.6 \mathrm{~km}$ of stands. $3.6 \mathrm{~km}$ of stream-bank vegetation do not need any treatments.

\section{Discussion and conclusion}

\section{Discussion}

The principle of the presented methodology is dividing of evaluated streams into sections. Within the frame of sections, the segments are determined. Stream-bank vegetation evaluation may be implemented by different procedures. Sections may be assessed as a whole, without segmentation. The advantages of this procedure are simplicity and possibility of large-scale evaluation. The disadvantages are generalization and insufficiency of data. Another procedure is evaluation and management aimed at particular trees. Assessment is detailed, but too demanding. The Presented methodology is a compromise between these procedures.

In contradiction with the methodology according to Šlezingr (2002), the presented methodology is more detailed and provides more data for the management plan. In contradiction with the methodology according to Fuksa (2001), the presented methodology is more suitable for application in practice. The methodology applied in Povodí Moravy s.p. (Mařák, 1996) concentrated on management planning, and it is suitable to use in practice. But this methodology has not been published yet.

In contradiction with the methodology according to Roth, Allan, Erickson (1996), and with the methodology according to Parsons, Thomas and Norris (2000), or with the Stream restoration evaluation assessment form (2006), presented methodology is specialized in stream-bank vegetation assessment. The stream restoration evaluation assessment form (2006) is 
applicable to the river evaluation. The presented methodology is more detailed in vegetation evaluation and provides more relevant data for management plan. The object of the methodology according to Coroi, Skeffington, Giller, et al. (2004) is the evaluation of forest sites, this methodology is more suitable for evaluating forests. But presented methodology is more suitable for application in rural landscape. Methodologies according to Shields (1991), Geyer, Nepple and Brooks (1993), and Abernethy and Rutherfurd (2000) are specialized in bank stability assessment. Methodology according to Burton, Smith and Cowley (2008) is applicable to the stream assessment and riparian vegetation evaluation in rural landscapes, especially in pastures (grazing ground). The objects of this methodology are stream-bank and vegetation indicators (vegetation composition, stream-bank alteration, stream-bank stability and cover, residual vegetation measurement, woody species regeneration, woody species use) and in-channel indicators (width, depth). Streams are evaluated in transects. In contradiction with the methodology according to Burton, Smith and Cowley (2008), the presented methodology is applicable to the evaluation of whole streams (sections of the streams) but evaluated streams are fractioned to the sections and segments in the evaluation process. The presented methodology is adapted to use in Europe (Czech Republic).

Coefficients used in the presented methodology (for example degree of species composition autochthonism, degree of species diversity, degree of vitality) were determined on the basis of published sources. In different environmental conditions, different structure types, species composition and physiological age may be determined. Therefore verification of the presented methodology on other examples of streams would be suitable. The next step would be structure-qualitative type determination.

The presented methodology, which is applicable in practice, is characterized by simplicity. At the same time the methodology provides sufficient data for management planning.

The goal of the management plan is treatment specification, aimed at a suitable condition of streamside stand achievement and maintenance. It would be suitable to implement the management planning on 3 grades. The $1^{\text {st }}$ grade includes strategy planning, which would determine long-term management principles and optimum conditions of the stream-bank vegetation. On the basis of a strategy plan, the tactical plan would be designed. The tactical plan would be parallel to the forest management plan. Finally the operation planning containing the detailed specification of treatment would be applied.

\section{Conclusion}

The presented methodology is applicable for evaluation of the stream-bank vegetation in rural landscapes. Assessed streams are divided into sections, delimited by natural or artificial barriers. Within the frame of sections, the segments are determined. The segments are parts of the section with similar characteristics (width, structure, species composition, etc.) in general. The segments are characterized by delimitation, flood plain and river-basin characteristics and by stream-bank vegetation. Stream-bank vegetation (streamside stands) is characterized by width, space structure, species composition, physiological age and by state of health.

The result of the methodology is the stream-bank vegetation database. The stream-bank vegetation database includes maps, databases, stream-bank vegetation evaluation and management theses. The map section includes general and detailed maps. Maps are generated by source maps digitalization in GIS software. Contents of general maps are evaluated stream display, division into sections and land use display. The scale of these maps is 1:10 000. Detailed maps include map of stand evaluation and map of the management proposal. These maps consist of line layers of streams and stream-bank vegetation (segments and sub-segments) and of point layers of segments delimitation and river log in kilometres. The detailed maps are connected with databases and shaped to a scale of display 1:2 000 .

Databases consist of section database, segment database and specifications of tree layer. The section database contains section identification, including hydrological order, hydrological log of beginning and end of the sections, length, classification (Strahler order, type of stream). The segment database includes identification, delimitation, flood plain and river-basin characteristics and stream-bank vegetation characteristics. The segments are identified according to the code. Segment delimitation data include river log of beginning and end of 
segment, proportion share of partial segments, length, mid-width and area. Flood plain data contain potential and recent conditions, land use and river-basin depth. Stream data include river basin material, information about bunding or scour erosion.

The object of stream-bank vegetation characteristic is description of stand, tree layer and shrub layer. The database includes data about width category, continuity, qualitative rates (development phase, autochtonity, species diversity, etc.) and species composition.

The specification of tree layer contains the detailed data about tree stand. The specification is generated for tree layers with a continuity of at least $40 \%$ and for species with a proportion of at least $10 \%$. The management proposal table is a part of segment database. The table includes treatment specification and data on treatment urgency.

The methodology is applied to $8.12 \mathrm{~km}$ of the Rakovec stream, $16.24 \mathrm{~km}$ of the banks are evaluated. The stream-bank vegetation database, including maps and databases, is generated. Spatial structure, species composition, development phase and vitality are evaluated. 13 basic structure types are distinguished within the frame of evaluated section.

The flood plain in the survey area is intensively utilized (mainly arable land). The width of the stream-bank vegetation is limited by land use of boundary land. $95 \%$ of evaluated banks reached the width of 3 to 10 meters.

The proportion of tree line stands with shrubs is $20 \%$. The proportion of tree line stands without shrub layer and narrow tree line stands is $16.1 \%$. Stands with discontinuous tree layer and shrub stands reached $35.4 \%$ of length of evaluated sections. Banks with solitaires, banks without woody vegetation and unclassified types reached $25.2 \%$ of length of evaluated sections.

$60 \%$ of evaluated tree layer is the $1^{\text {st }}$ class of species composition (nature nearly stands), this stand consists mainly of autochthonous species: common alder (Alnus glutinosa L), European ash (Fraxinus excelsior $L$ ) and willows (Salix sp. L). The main problem of species composition is alien or crossbred species representation, for example crossbred poplars (Populus $x$ canadensis Moench) or black locust (Robinia pseudoacacia L).

\section{References}

[1] Abernethy, B. \& Rutherfurd, ID. (2000). The effect of riparian tree roots on the mass-stability of riverbanks. Earth surface processes and landforms. 25(9), 927-931). Doi: 10.1002/10969837(200008)25:9\&lt;921::AID-ESP93\&gt;3.0.CO;2-7

[2] Ambros, Z. \& Štykar, J. (1999). Geobiocenologie I. Brno: Mendel University of Agriculture and Forestry.

[3] Bache, D, H. \& Macaskill, I, A. (1981). Vegetation in coastal and stream-bank protection. Landscape planning. 8(4): 363-385. Doi: 10.1016/0304-3924(81)90003-4.

[4] Buček, A. \& Lacina, J. (2002). Geobiocenologie II. Brno: Mendel University of Agriculture and Forestry.

[5] Burton, TA., Smith, SJ. \& Cowley, ER. (2008). Monitoring stream channels and riparian vegetation - Multiple indicators. Version 5.0. U.S. Department of the Interior, Bureau of land management. Idaho state office. Boise, ID. Retrieved from: http://oregonstate.edu/dept/range/sites/default/files/RNG455555PDFLinks/Burton_Monitorin g_Channels_and_Ripzones/Burton_2008.pdf

[6] Coroi, M., Skeffington, M.S., Giller, P., Smith, C., Gormally, M. \& O’Donovan, G. (2004). Vegetation diversity and stand structure in streamside forests in the south of Ireland. Forest Ecology and Management. 202(1-3): 39-57. Doi:10.1016/j.foreco.2004.06.034.

[7] Demek, M. et al. (2006). Manuál pro hydromorfologické hodnocení vodních toků.

[8] Ehrlich P. et al. (1992). Prozatímní metodické pokyny pro obnovu ekologické funkce upravených vodních toků s malým povodím. Metodika 9/92. Praha: VúMOP. 
[9] Chytrý, M., Kučera, T. \& Kočí, M. (2001). Katalog biotopů České republiky. Praha: Agentura ochrany prírody a krajiny.

[10] Geyer, W., Nepple, T. \& Brooks, K. (1993). Riparian vegetation and streambank stability in agroecosystems in National Convention of the Society-of-American-Foresters.

[11] Havlíčková, S. (2005). Hodnocení břehových porostů. In Říční krajina 3 (p. 107-111), Sborník príspěvků z konference Olomouc.

[12] Klimo, E., Hager, H., Matič, S., Anič, I. \& Kulhavý, J. (2008). Floodplain forests of temperate zones of Europe. Kostelec nad Černými lesy: Lesnická práce.

[13] Kolařík, J. et al. (2005). Péče o dřeviny rostoucí mimo les II. Vlašim: Český svaz ochránců prírody.

[14] Langhammer, J. et al. (2009). Vymezení typů útvarů povrchových vod. Praha: Univerzita Karlova v Praze.

[15] Marhoun K. et al. (1982). Dřevinný vegetační doprovod vodních toků. Brno: Hydroprojekt.

[16] Mařák, I. (1996). Bystřička - speciální hospodářský plán. Uherské Hradiště: Povodí Moravy.

[17] Mařák, I. (2000). Salaška - speciální hospodářský plán. Uherské Hradiště: Povodí Moravy.

[18] Novák L., Iblová M. \& Škopek V. (1986). Vegetace v úpravách vodních toků a nádrží. Praha: SNTL.

[19] Parsons, M., Thomas, M. \& Norris, R. (2000). Australian River Assessment System: Review of Physical River Assessment Methods - A Biological Perspective. Monitoring River Heath Initiative Technical Report no 21, Canberra: Commonwealth of Australia and University of Canberra. Retrieved from:

http://www.environment.gov.au/water/publications/environmental/rivers/nrhp/pubs/protocol2.pdf

[20] Patterson, D. W. (1976). Evaluation of habitats resulting from stream bank protection projects in Siskiyou and Mendocino counties, California. USDA Soil Conservation Service, Red Bluff CA.

[21] Roth, N., J. Allan, J. \& Erickson, D. (1996). Landscape influences on stream biotic integrity assessed at multiple spatial scales. Landscape Ecology, 11(3): 1-156. Doi: 10.1007/BF02447513.

[22] Somer, M., Švecová, R. \& Fuksa, J.K. (2001). Zpracování metodiky a mapování ekomorfologických struktur na českých a německých úsecích Labe. Praha: VúV T.G.M.

[23] Shields, F. D. (1991). Woody vegetation and riprap stability along the Sacramento River mile 84.5-119. Water resources bulletin. 27 (3), 527-536.

[24] Šimíček, V. (1999). Břehové a doprovodné porosty vodních toků - součást lužních ekosystémů. Praha: Agrospoj.

[25] Šlezingr M. \& Úradníček L. (2002): Vegetační doprovod vodních toků a nádrží. Brno: CERM.

[26] Šlezingr, M. \& Úřadníček, L. (2003). Bankside trees and srubs. Brno: CERM.

[27] Vyskot, I. et al. (2003): Quantification and Evaluation of Forest Functions on the Example of the Czech Republic. Praha: Margaret. 


\section{National (Czech) law:}

Act No. 114/92 Coll. on Nature and Landscape Protection

Act No. 254/2001 Coll. on Water and Amendment to Other Acts

Decree No. 84/1996 Coll. on Forest Management Planning

\section{European and international law:}

DIRECTIVE 2000/60/EC OF THE EUROPEAN PARLIAMENT AND OF THE COUNCIL

of 23 October 2000 establishing a framework for Community action in the field of water policy. Platte County Zoning Order of 1990 Article III, Section 400.350 
Appendices:

\begin{tabular}{|c|c|c|c|c|c|c|c|c|c|c|}
\hline \multirow{3}{*}{ 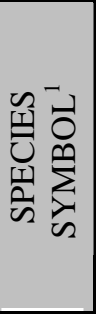 } & \multirow{3}{*}{ ENGLISH NAME $^{2}$} & \multirow{3}{*}{ SCIENTIFIC NAME $^{1}$} & \multirow{3}{*}{ 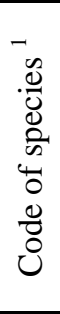 } & \multicolumn{7}{|c|}{$\begin{array}{l}\text { Site type according to Zlatník } \\
\text { (1956) }\end{array}$} \\
\hline & & & & तี & $\frac{1}{2}$ & 홈 & 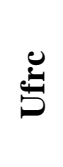 & 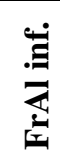 & $\sum_{\substack{\vdots \\
\vdots}}^{\dot{\Xi}}$ & $\ddot{z}$ \\
\hline & & & & 1 & 2 & 3 & 4 & 5 & 6 & 7 \\
\hline SM & Norway spruce & Picea abies (L.) Karsten & 1 & $\mathbf{0}$ & $\mathbf{0}$ & $\mathbf{0}$ & $\mathbf{0}$ & $\mathbf{0}$ & 0.1 & 0.3 \\
\hline SMX & Spruce (exotic) ${ }^{3}$ & & 9 & $\mathbf{0}$ & $\mathbf{0}$ & $\mathbf{0}$ & $\mathbf{0}$ & $\mathbf{0}$ & $\mathbf{0}$ & $\mathbf{0}$ \\
\hline JD & Silver fir & Abies alba Mill. & 10 & $\mathbf{0}$ & $\mathbf{0}$ & $\mathbf{0}$ & $\mathbf{0}$ & $\mathbf{0}$ & $\mathbf{0}$ & 0.1 \\
\hline JDX & Fir (exotic) ${ }^{4}$ & & 16 & $\mathbf{0}$ & $\mathbf{0}$ & $\mathbf{0}$ & $\mathbf{0}$ & $\mathbf{0}$ & $\mathbf{0}$ & $\mathbf{0}$ \\
\hline DG & Douglas fir & $\begin{array}{l}\text { Pseudotsuga menziesii } \\
\text { (Mirbel) Franco }\end{array}$ & 18 & $\mathbf{0}$ & $\mathbf{0}$ & $\mathbf{0}$ & $\mathbf{0}$ & $\mathbf{0}$ & $\mathbf{0}$ & $\mathbf{0}$ \\
\hline $\mathrm{BO}$ & Scotch pine & Pinus sylvestris L. & 20 & $\mathbf{0}$ & $\mathbf{0}$ & $\mathbf{0}$ & $\mathbf{0}$ & $\mathbf{0}$ & $\mathbf{0}$ & $\mathbf{0}$ \\
\hline $\mathrm{BOX}$ & Pine (exotic) ${ }^{5}$ & & 27 & 0 & 0 & 0 & 0 & 0 & 0 & $\mathbf{0}$ \\
\hline $\mathrm{KOS}$ & Dwarf pine (mountain p.) & Pinus mugo Turra & 28 & $\mathbf{0}$ & $\mathbf{0}$ & $\mathbf{0}$ & $\mathbf{0}$ & $\mathbf{0}$ & $\mathbf{0}$ & $\mathbf{0}$ \\
\hline $\mathrm{BL}$ & Bog pine (var. Rotundata) & Pinus rotundata Link. & 29 & $\mathbf{0}$ & $\mathbf{0}$ & $\mathbf{0}$ & $\mathbf{0}$ & $\mathbf{0}$ & $\mathbf{0}$ & $\mathbf{0}$ \\
\hline MD & European larch & Larix decidua Mill. & 30 & $\mathbf{0}$ & $\mathbf{0}$ & $\mathbf{0}$ & $\mathbf{0}$ & $\mathbf{0}$ & $\mathbf{0}$ & $\mathbf{0}$ \\
\hline MDX & Larch (exotic) & & 31 & $\mathbf{0}$ & $\mathbf{0}$ & $\mathbf{0}$ & $\mathbf{0}$ & $\mathbf{0}$ & $\mathbf{0}$ & $\mathbf{0}$ \\
\hline JX & Other conifer tree species & & 39 & $\mathbf{0}$ & $\mathbf{0}$ & $\mathbf{0}$ & $\mathbf{0}$ & $\mathbf{0}$ & $\mathbf{0}$ & $\mathbf{0}$ \\
\hline DB & English oak & Quercus robur L. & 40 & $\mathbf{0}$ & 0.8 & 0.6 & 0.7 & 0.3 & $\mathbf{0}$ & $\mathbf{0}$ \\
\hline DBZ & Sessile oak & $\begin{array}{l}\text { Quercus petraea (Mattyschka) } \\
\text { Liebl. }\end{array}$ & 42 & $\mathbf{0}$ & $\mathbf{0}$ & $\mathbf{0}$ & $\mathbf{0}$ & $\mathbf{0}$ & $\mathbf{0}$ & $\mathbf{0}$ \\
\hline DBP & $\begin{array}{l}\text { Eastern white oak (Dawny } \\
\text { oak) }\end{array}$ & Quercus pubescens Willd. & 44 & $\mathbf{0}$ & $\mathbf{0}$ & $\mathbf{0}$ & $\mathbf{0}$ & $\mathbf{0}$ & $\mathbf{0}$ & $\mathbf{0}$ \\
\hline DBX & Oak (exotic) ${ }^{6}$ & & 47 & $\mathbf{0}$ & $\mathbf{0}$ & $\mathbf{0}$ & $\mathbf{0}$ & $\mathbf{0}$ & $\mathbf{0}$ & $\mathbf{0}$ \\
\hline CER & Turkey oak & Quercus cerris L. & 48 & $\mathbf{0}$ & $\mathbf{0}$ & $\mathbf{0}$ & $\mathbf{0}$ & $\mathbf{0}$ & $\mathbf{0}$ & $\mathbf{0}$ \\
\hline $\mathrm{BK}$ & European beech & Fagus silvatica L. & 50 & $\mathbf{0}$ & $\mathbf{0}$ & $\mathbf{0}$ & $\mathbf{0}$ & $\mathbf{0}$ & 0.1 & 0.1 \\
\hline $\mathrm{HB}$ & European hornbeam & Carpinus betulus L. & 51 & $\mathbf{0}$ & $\mathbf{0}$ & $\mathbf{0}$ & 0.3 & $\mathbf{0}$ & $\mathbf{0}$ & 0 \\
\hline JV & Norway maple & Acer platanoides L. & 52 & $\mathbf{0}$ & $\mathbf{0}$ & $\mathbf{0}$ & 0.3 & 0.3 & $\mathbf{0}$ & 0 \\
\hline KL & Sycamore maple & Acer pseudoplatanus L. & 53 & $\mathbf{0}$ & $\mathbf{0}$ & $\mathbf{0}$ & $\mathbf{0}$ & $\mathbf{0}$ & 0.3 & 0.1 \\
\hline $\mathrm{BB}$ & Hedge maple & Acer campestre L. & 54 & $\mathbf{0}$ & $\mathbf{0}$ & 0.1 & 0.1 & $\mathbf{0}$ & $\mathbf{0}$ & 0 \\
\hline JVJ & Boxelder & Acer negundo L. & 55 & $\mathbf{0}$ & $\mathbf{0}$ & $\mathbf{0}$ & $\mathbf{0}$ & $\mathbf{0}$ & $\mathbf{0}$ & $\mathbf{0}$ \\
\hline JVX & Maple (exotic) & & 56 & $\mathbf{0}$ & $\mathbf{0}$ & $\mathbf{0}$ & $\mathbf{0}$ & $\mathbf{0}$ & $\mathbf{0}$ & $\mathbf{0}$ \\
\hline JS & Common ash & Fraxinus excelsior L. & 57 & $\mathbf{0}$ & 0.4 & 0.4 & 0.3 & 0.6 & 0.6 & 0.1 \\
\hline JSA & White ash & Fraxinus americana L. & 58 & $\mathbf{0}$ & $\mathbf{0}$ & $\mathbf{0}$ & $\mathbf{0}$ & $\mathbf{0}$ & $\mathbf{0}$ & $\mathbf{0}$ \\
\hline JSU & Raywood ash & Fraxinus angustifolia Vahl & 59 & 0.1 & 0.4 & 0.4 & 0.1 & $\mathbf{0}$ & $\mathbf{0}$ & $\mathbf{0}$ \\
\hline $\mathrm{JL}$ & Smooth elm & Ulmus minor Mill. & 60 & $\mathbf{0}$ & 0.3 & 0.3 & 0.3 & 0.3 & $\mathbf{0}$ & $\mathbf{0}$ \\
\hline JLH & Scotch elm & Ulmus glabra Hudson & 61 & $\mathbf{0}$ & $\mathbf{0}$ & $\mathbf{0}$ & $\mathbf{0}$ & $\mathbf{0}$ & 0.3 & 0.1 \\
\hline $\mathrm{JLV}$ & Clay fraction & Ulmus laevis Pallas & 62 & $\mathbf{0}$ & 0.3 & 0.3 & 0.1 & $\mathbf{0}$ & $\mathbf{0}$ & $\mathbf{0}$ \\
\hline $\mathrm{AK}$ & Black locust & Robinia pseudacacia L. & 63 & $\mathbf{0}$ & $\mathbf{0}$ & $\mathbf{0}$ & $\mathbf{0}$ & $\mathbf{0}$ & $\mathbf{0}$ & $\mathbf{0}$ \\
\hline $\mathrm{BR}$ & European white birch & Betula pendula Roth & 64 & $\mathbf{0}$ & $\mathbf{0}$ & 0.1 & 0.1 & 0.1 & 0.1 & 0.1 \\
\hline BRP & Davny birch & Betula pubescens Ehrh. & 65 & $\mathbf{0}$ & $\mathbf{0}$ & $\mathbf{0}$ & $\mathbf{0}$ & $\mathbf{0}$ & $\mathbf{0}$ & 0 \\
\hline JR & European mountain ash & Sorbus aucuparia L. & 66 & $\mathbf{0}$ & $\mathbf{0}$ & 0.1 & $\mathbf{0}$ & 0.1 & 0.1 & 0.1 \\
\hline
\end{tabular}




\begin{tabular}{|c|l|l|c|c|c|c|c|c|c|c|}
\hline BRK & Wild service tree & Sorbus torminalis (L.) Crantz & 67 & $\mathbf{0}$ & $\mathbf{0}$ & $\mathbf{0 . 1}$ & $\mathbf{0}$ & $\mathbf{0}$ & $\mathbf{0}$ & $\mathbf{0}$ \\
\hline MK & Whitebeam & Sorbus aria (L.) Crantz & 68 & $\mathbf{0}$ & $\mathbf{0}$ & $\mathbf{0}$ & $\mathbf{0}$ & $\mathbf{0}$ & $\mathbf{0}$ & $\mathbf{0}$ \\
\hline OR & Black walnut & Juglans regia L. & 70 & $\mathbf{0}$ & $\mathbf{0}$ & $\mathbf{0}$ & $\mathbf{0}$ & $\mathbf{0}$ & $\mathbf{0}$ & $\mathbf{0}$ \\
\hline ORC & Common walnut & Juglans nigra L. & 71 & $\mathbf{0}$ & $\mathbf{0}$ & $\mathbf{0}$ & $\mathbf{0}$ & $\mathbf{0}$ & $\mathbf{0}$ & $\mathbf{0}$ \\
\hline TR & Sweet cherry & Cerasus avium (L.) & 74 & $\mathbf{0}$ & $\mathbf{0}$ & $\mathbf{0 . 1}$ & $\mathbf{0 . 1}$ & $\mathbf{0 . 1}$ & $\mathbf{0 . 1}$ & $\mathbf{0}$ \\
\hline STR & Bird cherry & Padus avium ill. & 75 & $\mathbf{0 . 1}$ & $\mathbf{0 . 1}$ & $\mathbf{0 . 1}$ & $\mathbf{0 . 1}$ & $\mathbf{0 . 1}$ & $\mathbf{0 . 1}$ & $\mathbf{0 . 1}$ \\
\hline HR & Wild pear & Pyrus pyraster (L.) Burgsd. & 76 & $\mathbf{0}$ & $\mathbf{0}$ & $\mathbf{0}$ & $\mathbf{0 . 1}$ & $\mathbf{0}$ & $\mathbf{0}$ & $\mathbf{0}$ \\
\hline JB & Crab apple & Malus sylvestris Mill. & 77 & $\mathbf{0}$ & $\mathbf{0}$ & $\mathbf{0}$ & $\mathbf{0 . 1}$ & $\mathbf{0}$ & $\mathbf{0}$ & $\mathbf{0}$ \\
\hline LP & Small-leaved linden & Tillia cordata Mill. & 80 & $\mathbf{0 . 1}$ & $\mathbf{0 . 1}$ & $\mathbf{0 . 1}$ & $\mathbf{0 . 3}$ & $\mathbf{0 . 3}$ & $\mathbf{0 . 1}$ & $\mathbf{0 . 1}$ \\
\hline LPV & Large-leaved linden & Tillia platyphyllos Scop. & 81 & $\mathbf{0}$ & $\mathbf{0}$ & $\mathbf{0}$ & $\mathbf{0}$ & $\mathbf{0}$ & $\mathbf{0}$ & $\mathbf{0}$ \\
\hline OL & Black alder (European alder) & Alnus glutinosa (L.) Gaertner & 83 & $\mathbf{0 . 8}$ & $\mathbf{0 . 1}$ & $\mathbf{0 . 1}$ & $\mathbf{0 . 1}$ & $\mathbf{0 . 8}$ & $\mathbf{0 . 8}$ & 0.3 \\
\hline OLS & Speckled alder & Alnus incana (L.) Moench & 84 & $\mathbf{0}$ & $\mathbf{0}$ & $\mathbf{0}$ & $\mathbf{0}$ & $\mathbf{0}$ & $\mathbf{0 . 1}$ & 1 \\
\hline OS & European aspen & Populus tremula L. & 86 & $\mathbf{0 . 4}$ & $\mathbf{0 . 3}$ & $\mathbf{0 . 6}$ & $\mathbf{0 . 3}$ & $\mathbf{0 . 1}$ & $\mathbf{0 . 1}$ & 0.1 \\
\hline TP & White poplar & Populus alba L. & 87 & $\mathbf{0 . 4}$ & $\mathbf{0 . 3}$ & $\mathbf{0 . 6}$ & $\mathbf{0 . 3}$ & $\mathbf{0}$ & $\mathbf{0}$ & 0 \\
\hline TPC & Black poplar & Populus nigra L. & 88 & $\mathbf{0 . 4}$ & $\mathbf{0 . 3}$ & $\mathbf{0 . 6}$ & $\mathbf{0 . 3}$ & $\mathbf{0}$ & $\mathbf{0}$ & 0 \\
\hline TPS & Hybrid poplar & Populus x canadensis Moench. & 90 & $\mathbf{0}$ & $\mathbf{0}$ & $\mathbf{0}$ & $\mathbf{0}$ & $\mathbf{0}$ & $\mathbf{0}$ & $\mathbf{0}$ \\
\hline JIV & Goat willow & Salix caprea L. & 91 & $\mathbf{0 . 1}$ & $\mathbf{0 . 1}$ & $\mathbf{0 . 1}$ & $\mathbf{0 . 1}$ & $\mathbf{0 . 1}$ & $\mathbf{0 . 1}$ & $\mathbf{0 . 1}$ \\
\hline VR & White willow, Crack willow & Salix alba, Salix fragilis L. & 92 & $\mathbf{0 . 6}$ & $\mathbf{0 . 1}$ & $\mathbf{0 . 1}$ & $\mathbf{0 . 1}$ & $\mathbf{0 . 3}$ & $\mathbf{0 . 3}$ & $\mathbf{0 . 3}$ \\
\hline KS & Horse chestnut & Aesculus hippocastanum L. & 83 & $\mathbf{0}$ & $\mathbf{0}$ & $\mathbf{0}$ & $\mathbf{0}$ & $\mathbf{0}$ & $\mathbf{0}$ & $\mathbf{0}$ \\
\hline LX & broadleaves (other species) $^{8}$ & & 97 & $\mathbf{0}$ & $\mathbf{0}$ & $\mathbf{0}$ & $\mathbf{0}$ & $\mathbf{0}$ & $\mathbf{0}$ & $\mathbf{0}$ \\
\hline
\end{tabular}

Appendix No. 1: Maximum Potential Species Representation

${ }^{1}$ symbol of the species, code of the species and scientific name: according to Appendix No. 4 to Decree No. 84/1996 Coll. on Forest Management Planning.

${ }^{2}$ English names according to Šlezingr, Úradníček (2003)

${ }^{3}$ Spruce (exotic), includes: Picea pungens Engelm. (symbol SMP), Picea mariana (Muller) B.S. et P. (symbol SMC), Picea glauca (Moench) Voss. (symbol SMS), Picea omorica (Pančič) Purkyně (symbol SMO), Picea engelmanni Engelm. (symbol SME).

${ }^{4}$ Fir (exotic), includes: Abies grandis (Douglas) Lindl. (symbol JDO), Abies concolor (Gord.) Hilldebr. (symbol JDJ), Abies nordmanniana (Steven) Spach. (symbol JDK), Abies procera Rehder (symbol JDV)

${ }^{5}$ Pine exotic, includes: Pinus nigra Amold (symbol BOC), Pinus banksiana Lamb. (symbol $B K S$ ), Pinus strobus L. (symbol VJ), Pinus cembra L. (symbol LMB), Pinus contorta Loudon (symbol BOP)

${ }^{6}$ Oak (exotic), includes: Quercus rubra L. (symbol DBC), Quercus pubescens Willd. (symbol $D B P$ ), Quercus palustris Muenchh. (symbol DBB).

${ }^{7}$ Poplar (hybrid)- Populus $x$ canadensis (P. deltoides $x$ nigra) Moench (Hybrid Black Poplar, Carolina poplar)

${ }^{8}$ broadleaves (other species), includes: Tillia tomentosa Moench. (symbol LPS), Platanus $x$ hispanica Mill.(symbol PL), Ailanthus altissima (Mill.), Swingle (symbol PJ), other hardwood (symbol LTX) and softwood species (symbol LMX) 


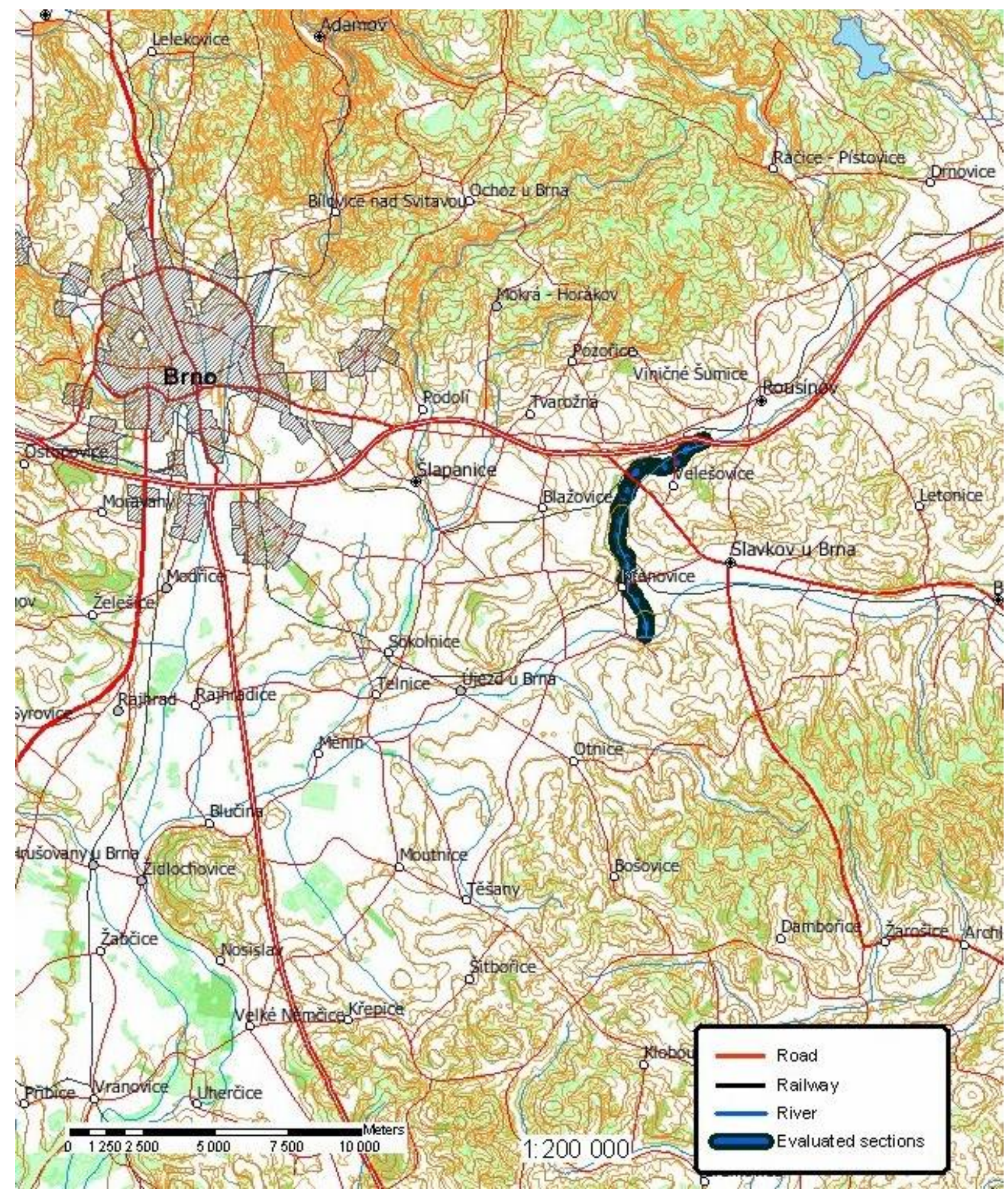

Appendix No. 2: Localization of Evaluated Sections 


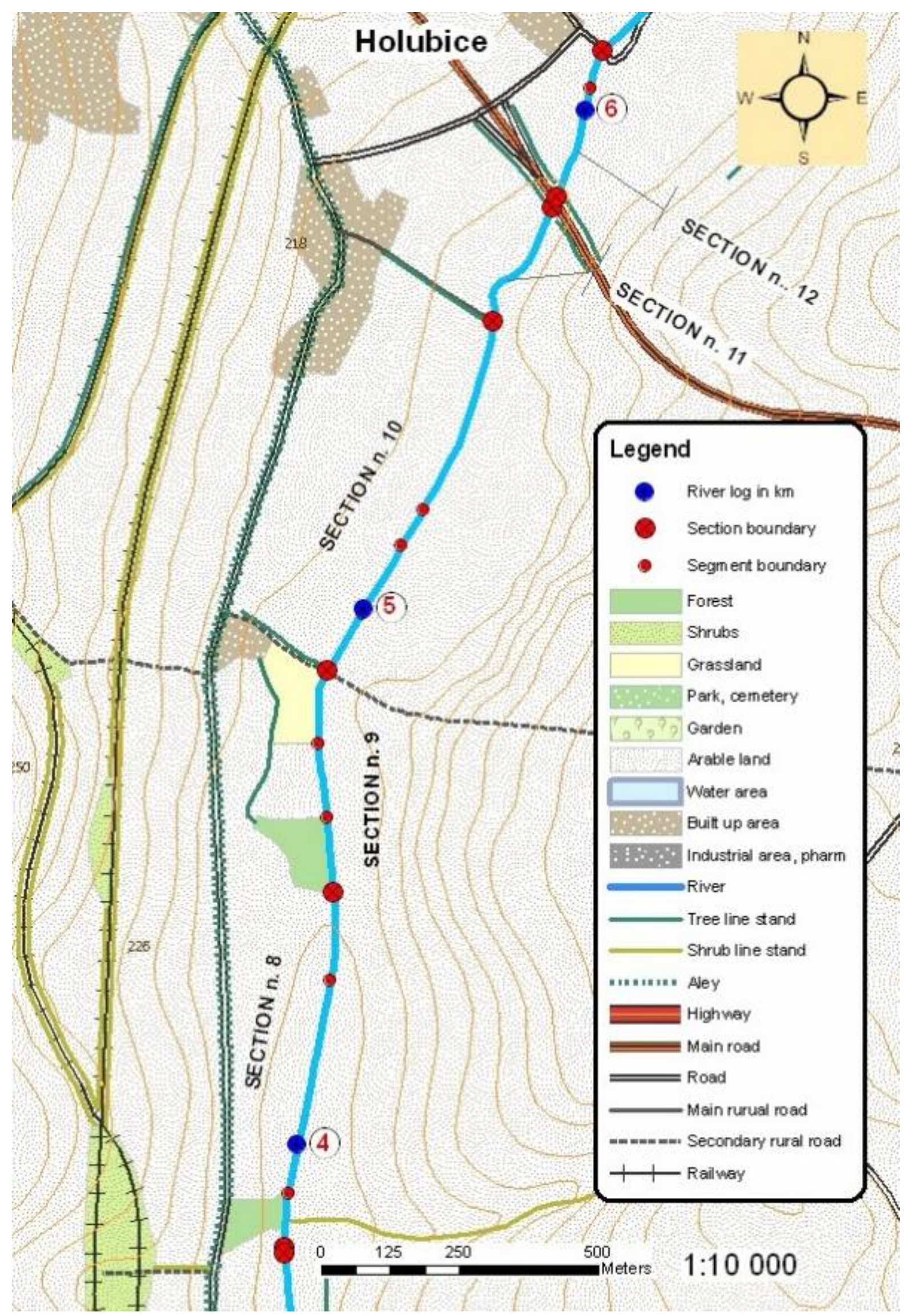

Appendix No. 3: General Map 


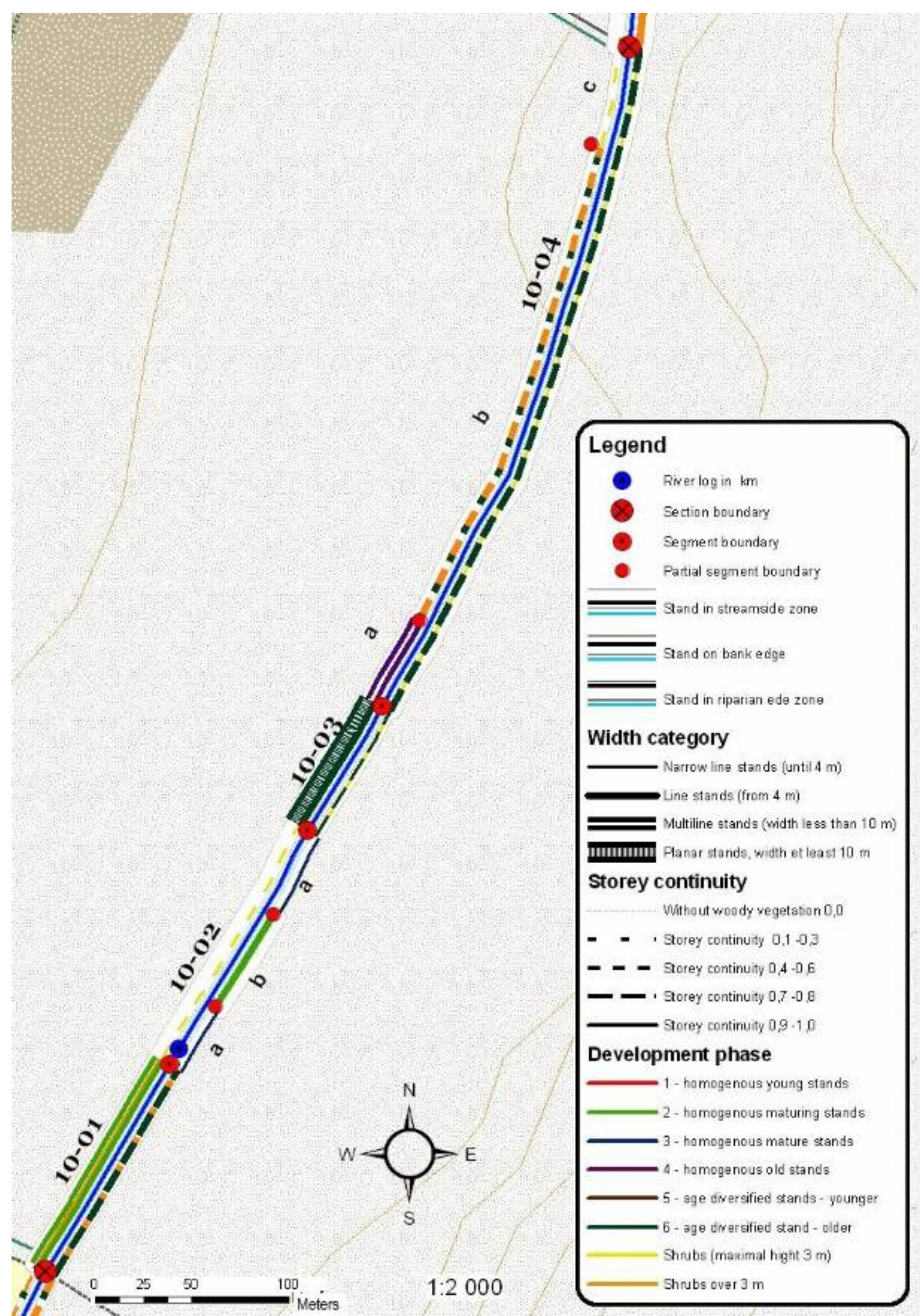

Appendix No. 4: Detailed Map - Map of Evaluation 


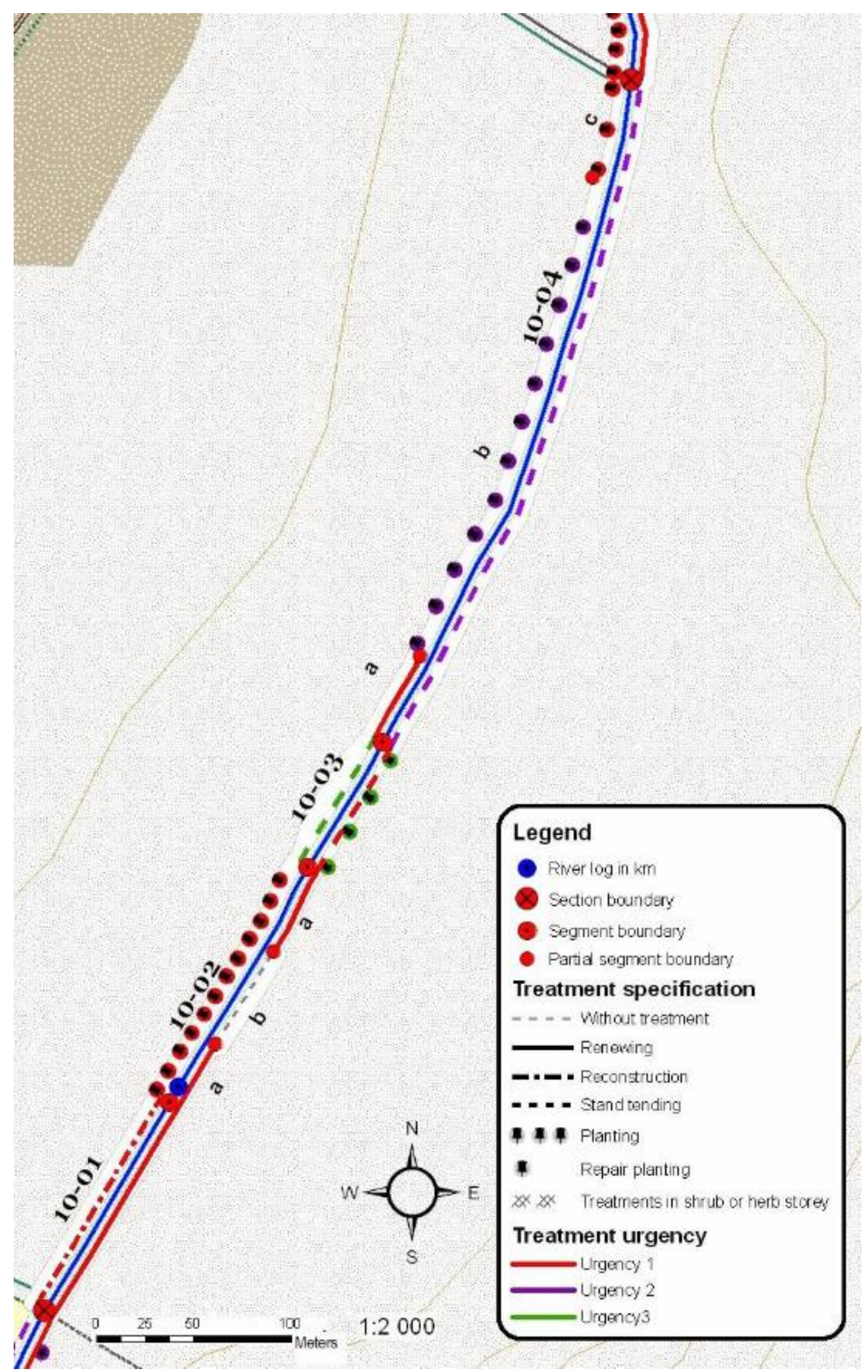

Appendix No. 5: Detailed Map - Map of Management Proposal 